\title{
Astronomical calibration of the Ypresian timescale: implications for seafloor spreading rates and the chaotic behavior of the solar system?
}

\author{
Thomas Westerhold ${ }^{1}$, Ursula Röhl ${ }^{1}$, Thomas Frederichs ${ }^{2}$, Claudia Agnini ${ }^{3}$, Isabella Raffi ${ }^{4}$, James C. Zachos $^{5}$, and \\ Roy H. Wilkens ${ }^{6}$ \\ ${ }^{1}$ MARUM - Center for Marine Environmental Sciences, University of Bremen, Leobener Straße, 28359 Bremen, Germany \\ ${ }^{2}$ Faculty 5 Geosciences, University of Bremen, 28359 Bremen, Germany \\ ${ }^{3}$ Dipartimento di Geoscienze, Università degli Studi di Padova, via G. Gradenigo 6, 35131 Padua, Italy \\ ${ }^{4}$ Dipartimento di Ingegneria e Geologia (InGeo) - CeRSGeo, Universitaà degli Studi “G. d'Annunzio” Chieti-Pescara, \\ via dei Vestini 31, 66013 Chieti-Pescara, Italy \\ ${ }^{5}$ Department of Earth and Planetary Sciences, University of California Santa Cruz, 1156 High Street, Santa Cruz, \\ CA 95064, USA \\ ${ }^{6}$ Institute of Geophysics and Planetology, University of Hawai’i, Honolulu, HI 96822, USA
}

Correspondence to: Thomas Westerhold (twesterhold@marum.de)

Received: 8 February 2017 - Discussion started: 10 February 2017

Revised: 24 July 2017 - Accepted: 7 August 2017 - Published: 11 September 2017

\begin{abstract}
To fully understand the global climate dynamics of the warm early Eocene with its reoccurring hyperthermal events, an accurate high-fidelity age model is required. The Ypresian stage (56-47.8 Ma) covers a key interval within the Eocene as it ranges from the warmest marine temperatures in the early Eocene to the long-term cooling trends in the middle Eocene. Despite the recent development of detailed marine isotope records spanning portions of the Ypresian stage, key records to establish a complete astronomically calibrated age model for the Ypresian are still missing. Here we present new high-resolution X-ray fluorescence (XRF) core scanning iron intensity, bulk stable isotope, calcareous nannofossil, and magnetostratigraphic data generated on core material from ODP Sites 1258 (Leg 207, Demerara Rise), 1262, 1263, 1265, and 1267 (Leg 208, Walvis Ridge) recovered in the equatorial and South Atlantic Ocean. By combining new data with published records, a $405 \mathrm{kyr}$ eccentricity cyclostratigraphic framework was established, revealing a 300$400 \mathrm{kyr}$ long condensed interval for magnetochron C22n in the Leg 208 succession. Because the amplitudes are dominated by eccentricity, the XRF data help to identify the most suitable orbital solution for astronomical tuning of the Ypresian. Our new records fit best with the La2010b numerical
\end{abstract}

solution for eccentricity, which was used as a target curve for compiling the Ypresian astronomical timescale (YATS). The consistent positions of the very long eccentricity minima in the geological data and the La2010b solution suggest that the macroscopic feature displaying the chaotic diffusion of the planetary orbits, the transition from libration to circulation in the combination of angles in the precession motion of the orbits of Earth and Mars, occurred $\sim 52 \mathrm{Ma}$. This adds to the geological evidence for the chaotic behavior of the solar system. Additionally, the new astrochronology and revised magnetostratigraphy provide robust ages and durations for Chrons $\mathrm{C} 21 \mathrm{n}$ to $\mathrm{C} 24 \mathrm{n}$ (47-54 Ma), revealing a major change in spreading rates in the interval from 51.0 to $52.5 \mathrm{Ma}$. This major change in spreading rates is synchronous with a global reorganization of the plate-mantle system and the chaotic diffusion of the planetary orbits. The newly provided YATS also includes new absolute ages for biostratigraphic events, magnetic polarity reversals, and early Eocene hyperthermal events. Our new bio- and magnetostratigraphically calibrated stable isotope compilation may act as a reference for further paleoclimate studies of the Ypresian, which is of special interest because of the outgoing warming and increasingly cooling phase. Finally, our approach of integrating the 
complex comprehensive data sets unearths some challenges and uncertainties but also validates the high potential of chemostratigraphy, magnetostratigraphy, and biostratigraphy in unprecedented detail being most significant for an accurate chronostratigraphy.

\section{Introduction}

The Ypresian stage, from 56.0 to $47.8 \mathrm{Ma}$, represents the first $\sim 8$ million years of the Eocene epoch (Vandenberghe et al., 2012), an interval characterized by the warmest deep-sea temperatures of the Cenozoic era (Zachos et al., 2008), multiple transient global warming events (Cramer et al., 2003; Lourens et al., 2005; Agnini et al., 2009; Galeotti et al., 2010; Leon-Rodriguez and Dickens 2010; Stap et al., 2010; Zachos et al., 2010; Sexton et al., 2011; Slotnick et al., 2012; Littler et al., 2014; Kirtland Turner et al., 2014; Lauretano et al., 2015, 2016), and major faunal turnovers (Thomas and Shackleton, 1996; Gingerich, 2003; Clyde et al., 2007). Climatic records from the Ypresian greenhouse are of special interest because they potentially capture the behavior of Earth's climate system under $p \mathrm{CO}_{2}$ concentrations likely to be reached in the near future (Zachos et al., 2008; Meinshausen et al., 2011). For the detailed reconstruction of the Eocene greenhouse climate system, a complete, precise, and highly accurate stratigraphic framework to determine rates of climatic processes and timing of events is required.

Despite the recent progress in construction of astronomically calibrated age models for the Eocene using geochemical records (Cramer et al., 2003; Lourens et al., 2005; Westerhold et al., 2007; Galeotti et al., 2010; Jovane et al., 2010; Westerhold et al., 2012, 2014, 2015; Westerhold and Röhl, 2013; Littler et al., 2014; Lauretano et al., 2016), a fully consistent astrochronology for the Ypresian is not yet available. Two major issues have to be solved to achieve a complete Ypresian astronomical timescale (YATS): (1) the "50 Ma discrepancy" in magnetostratigraphy (Vandenberghe et al., 2012; Westerhold et al., 2015) and (2) the exact number of 405 kyr eccentricity cycles in magnetochron C23 (Lauretano et al., 2016).

The 50 Ma discrepancy arises from the short duration of magnetochron C23n.2n in Ocean Drilling Program (ODP) Site 1258 data (Suganuma and Ogg, 2006; Westerhold and Röhl, 2009) that results in a very unlikely abrupt global increase in spreading rate for this chron only at around $50 \mathrm{Ma}$ (Vandenberghe et al., 2012). Assuming a $400 \mathrm{kyr}$ longer duration for Chron $\mathrm{C} 22 \mathrm{r}$ in the same record would result in lower spreading rates than calculated on the basis of the standard geomagnetic polarity timescale (GPTS) using the synthetic magnetic anomaly profile of the South Atlantic (Cande and Kent, 1992, 1995; CK95). However, the Site $1258 \mathrm{mag}$ netostratigraphy is currently the only available record covering the entire Ypresian. Paleomagnetic interpretation for sediments from Site 1258 is difficult because the core was retrieved by rotary drilling. Minicores from Site 1258 gave a relatively good magnetostratigraphy but it is based on a rather subjective method of polarity interpretation (Suganuma and Ogg, 2006). After revision of the composite record of Site 1258, the interpretation was improved (Westerhold and Röhl, 2009), but the interpretation for Chrons C22r, $\mathrm{C} 23 \mathrm{n}$, and $\mathrm{C} 23 \mathrm{r}$ remained ambiguous.

Eccentricity-modulated precession cycles in X-ray fluorescence (XRF) core scanning iron $(\mathrm{Fe})$ intensities from Site 1258 and Leg 208 sites helped to set up the first cyclostratigraphic age models for the Ypresian (Westerhold et al., 2007; Westerhold and Röhl 2009). High-resolution bulk and benthic stable isotope data for the early (Cramer et al., 2003; Zachos et al., 2010; Stap et al., 2010; Littler et al., 2014; Lauretano et al., 2015, 2016), middle (Kirtland Turner et al., 2014), and late Ypresian (Sexton et al., 2011) showed exceptionally strong 100 and $405 \mathrm{kyr}$ eccentricity cycle variations that were partly utilized for age model construction. In order to test the $50 \mathrm{Ma}$ discrepancy and the astronomical age model at ODP Site 1258, high-resolution benthic stable isotope records spanning 54 to 49 Ma were compiled from ODP Site 1262 (Littler et al., 2014; Lauretano et al., 2015) and Site 1263 (Stap et al., 2010; Lauretano et al., 2015, 2016) and were astronomically tuned to the La2010d (Laskar et al., 2011a) orbital solution (Lauretano et al., 2016). In theory, the dominant eccentricity-related cyclicity in this interval should enable development of a robust astrochronology. However, a period of low-amplitude variability and a major shift in benthic $\delta^{13} \mathrm{C}$ data in Chron C23n and upper Chron C23r complicate the identification of the correct number of $405 \mathrm{kyr}$ cycles. The favored age model in Lauretano et al. (2016) proposes two $405 \mathrm{kyr}$ cycles in this complex interval, which provided absolute age estimates for early Eocene hyperthermal events. The two $405 \mathrm{kyr}$ cycle age model is favored because it assumes constant sedimentation rates. However, it did not solve the $50 \mathrm{Ma}$ discrepancy because the duration for C23n.2n is much too short (295 kyr) compared to CK95 (696 kyr) in ODP 1258.

To establish a complete YATS with consistent GPTS ages, a new deep-sea magneto-cyclostratigraphic record is needed to test the ODP Site 1258 magnetostratigraphy. In particular, the durations of Chrons C22 and C23 have to be evaluated. Here we present a new complete magnetostratigraphy spanning Chron $\mathrm{C} 21 \mathrm{n}$ to $\mathrm{C} 24 \mathrm{n}$ by integrating records from ODP Leg 208 Sites 1262, 1263, 1265, and 1267. New XRF core scanning data and core images are used for ultra-highresolution correlation between the Leg 208 sites. New calcareous nannofossil data from Sites 1258, 1263, and 1265 are presented and combined with published datums for direct calibration to magnetostratigraphy and revision of age datums. After integration of Leg 208 and ODP Leg 207 Site 1258 isotope data with new XRF data and core images, a cyclostratigraphic framework was compiled that was subsequently astronomically tuned to the La2010 (Laskar et al., 2011a) orbital solution. This study provides the first com- 


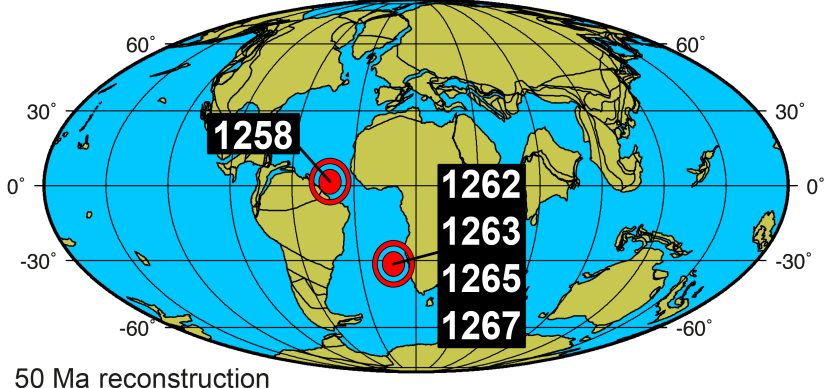

Figure 1. Location of ODP Site 1258 and Leg 208 sites on a $50 \mathrm{Ma}$ paleogeographic reconstruction in Mollweide projection (from http: //www.odsn.de).

plete and consistent bio-, chemo-, and magnetostratigraphy for the Ypresian stage. Our new data sets combining two regional records of ODP Legs 207 and 208 reveal unprecedented insight into possible challenges and uncertainties but also demonstrate the high potential of detailed chemostratigraphy, magnetostratigraphy, and biostratigraphy that will be the prerequisite for the major field of chronostratigraphy.

\section{Material and methods}

New data for this study were generated from sediment cores retrieved during ODP Leg 207 (Site 1258; Erbacher et al., 2004) and Leg 208 (Sites 1262, 1263, 1265, 1267; Zachos et al., 2004). The carbonate-rich sequences drilled at the equatorial Atlantic Demerara Rise (Leg 207) and the southeast Atlantic Walvis Ridge (Leg 208, Fig. 1) were recovered from multiple holes combined with composite records. For Sites 1262 and 1265 the shipboard composite depth was used (mcd - meters composite depth) for analysis (Zachos et al., 2004). For Sites 1258, 1263, and 1267 the revised composite record was applied (rmcd - revised composite depth; Westerhold et al., 2007, 2015; Westerhold and Röhl, 2009) for further analysis.

\subsection{XRF core scanner data}

To obtain a complete record for the Ypresian, published data had to be combined with the new XRF Fe core scanning data. The newly acquired data presented here have been measured on the three XRF core scanners at MARUM - Center for Marine Environmental Sciences, University of Bremen, with various hardware generations and under different settings (for details see Supplement). Site 1262 XRF data were obtained from 92.74-104.57 and $111.10-112.40 \mathrm{mcd}$, and were combined with data from Westerhold et al. (2007, 2012). Site 1263 data reported here are from 168.08 to $289.00 \mathrm{rmcd}$ and were combined with data from Westerhold et al. (2007). Site 1265 XRF data were measured from 228.10 to $275.00 \mathrm{mcd}$ and merged with data from Wester- hold et al. (2007). New Site 1267 XRF data were generated from 153.12 to 236.53 rmcd Settings for XRF core scanning of Site 1258 are given in Westerhold and Röhl (2009). Here we report the data from 134.61 to $212.49 \mathrm{rmcd}$ for Site 1258 . Combined with published data, 18000 new XRF core scanning data points (see Supplement) result in a total of more than 30000 data points covering the latest Paleocene and Ypresian. This enormous data set is the prerequisite for correlating the five drill sites in detail.

\subsection{Bulk stable isotope data}

To close a stratigraphic gap in the stable isotope record for Site 1263 , a section ( 230.50 to $239.00 \mathrm{rmcd}$ ) of nearby Site 1265 was selected. A total of 369 sediment samples were collected, freeze-dried, and powdered (Table S8 in the Supplement). The $\delta^{13} \mathrm{C}$ and $\delta^{18} \mathrm{O}$ values were measured at MARUM - Center for Marine Environmental Sciences, University of Bremen, and are reported relative to the Vienna Pee Dee Belemnite international standard, determined via adjustment to calibrated in-house standards and NBS-19. Analyses at MARUM were carried out on a Finnigan MAT 251 mass spectrometer equipped with an automated carbonate preparation line (Kiel III). The carbonate was reacted with orthophosphoric acid at $75^{\circ} \mathrm{C}$. Analytical precision based on replicate analyses of an in-house standard (Solnhofen Limestone) averaged $0.03 \% \circ(1 \sigma)$ for $\delta^{13} \mathrm{C}$ and $0.06 \% \circ(1 \sigma)$ for $\delta^{18} \mathrm{O}$ for samples measured in 2014 and $0.04 \%$ for $\delta^{13} \mathrm{C}$ and $0.04 \%$ for $\delta^{18} \mathrm{O}$ for samples run in 2015 .

Published stable isotope data also used in this study have been compiled from Lourens et al. (2005), Zachos et al. (2005, 2010), McCarren et al. (2008), Stap et al. (2009, 2010), Sexton et al. (2011), Westerhold et al. (2012, 2015), Kirtland Turner et al. (2014), Littler et al. (2014), and Lauretano et al. $(2015,2016)$. All data are provided in the Supplement (and PANGAEA) relative to the Site 1263 depth and with the tuned age added.

\subsection{Paleomagnetic data Leg 208}

Natural remanent magnetization (NRM) was measured on 400 discrete cube samples (dimensions $2 \mathrm{~cm} \times 2 \mathrm{~cm} \times 2 \mathrm{~cm}$ ) to document magnetic polarity boundaries $\mathrm{C} 20 \mathrm{r}$ to $\mathrm{C} 24 \mathrm{r}$ at ODP Sites 1262 (64), 1263 (128), 1265 (115), and 1267 (89). Discrete samples were analyzed at the Faculty of Geosciences, University of Bremen. Paleomagnetic directions and magnetization intensities were measured on a cryogenic magnetometer (2G Enterprises model $755 \mathrm{HR}$ ). NRM was measured on each sample before being subjected to a systematic alternating field demagnetization treatment involving steps of 7.5, 10, 15, 20, 25, 30, 40, and $60 \mathrm{mT}$. Intensities of orthogonal magnetic components of the remanent magnetization were measured after each step. Raw inclination, declination, and intensity data for each measurement step are provided in Tables S17-S20 in the Supplement. The calcu- 
lated characteristic remanent magnetization in Tables S21S25 and the magnetostratigraphic interpretations, including published data, are recorded in Tables S26-S30 for each of the five sites.

\subsection{Calcareous nannofossils at ODP Sites 1258, 1263 , and 1265}

Smear slides were processed following the standard procedures described in Bown et al. (1998) in order to investigate calcareous nannofossil assemblages. High-resolution semiquantitative counting methods, which consist of counting the number of forms ascribed to the same taxon detected in or normalized to a prefixed area (i.e., $1 \mathrm{~mm}^{2}$; Backman and Shackleton, 1983; Agnini et al., 2014), were used. These counts provide very detailed abundance patterns, which permit the precise identification of the position of each biohorizon, especially in those cases in which either the marker species displays an overall uneven distribution or a marker species is rare and discontinuous at the base and top of its stratigraphic range. On this basis and according to Agnini et al. (2014), six types of biohorizons are adopted, these are base rare (Br), base (B), base common and continuous (Bc), top (T), top common and continuous (Tc), and crossover (X). In two cases we used the increase-decrease in abundance of taxa (i.e., Fasciculithus spp., Zygrhablithus bijugatus) to define additional biohorizons. Taxonomic concepts adopted in this study are those of Perch-Nielsen (1985) and Agnini et al. (2007).

Calcareous nannofossil biostratigraphic analyses were newly performed or refined for the early Eocene of ODP Sites 1258, 1263, and 1265. The biohorizons used in different low-latitude to midlatitude zonations (Martini, 1971; Okada and Bukry, 1980; Agnini et al., 2014), as well as additional biohorizons, were recognized. A set of 168 samples were analyzed from the Demerara Rise (equatorial Atlantic) which allows for the identification of 40 biohorizons. At Walvis Ridge (SE Atlantic), a total of 181 samples were studied from ODP Sites 1263 (77) and 1265 (104), which permits the detection of 27 biohorizons. New data were integrated with ship data or other published results to obtain a more complete and reliable data set. Tables of the calcareous nannofossil biohorizons are given in Tables S31-S35.

\section{Results}

All data generated within and available data compiled for this study are combined in the data set file and available open access online at http://doi.pangaea.de/10.1594/PANGAEA. 871246.

\subsection{XRF core scanning results}

$\mathrm{Fe}$ intensity data reveal the cyclic pattern commonly observed for the interval from PETM to ETM-2 (Westerhold et al., 2007; Littler et al., 2014), with higher values in darker, more clay-rich layers. A decrease in carbonate content around $51 \mathrm{Ma}$ for all sites (Zachos et al., 2004) is reflected by overall higher $\mathrm{Fe}$ intensities. Multiple distinct peaks in Fe data for Chrons C22 and C23n correspond to strikingly bundled sets of clay-rich dark intervals for all sites. At Site 1262 the XRF Fe record ends with the shoaling of the carbonate compensation depth (CCD) above the site in Chron C21r around 93 mcd (Zachos et al., 2004). Generally, the records from Sites 1262 and 1267 are of lower resolution than those from Sites 1263 and 1265 due to the regional decline in carbonate accumulation rates with increasing water depth. Site 1263 shows the most persistent high-resolution XRF Fe intensity signal. A gap in the 1263 record from 229.15 to 233.68 rmcd caused by a drilling disturbance (Zachos et al., 2004) can successfully be bridged by the records from Sites 1265 and 1267. The high-resolution XRF Fe data show consistent patterns that are required to do a detailed site-to-site correlation and integration of Leg 208 Sites 1262, 1263, 1265, and 1267. New XRF Fe intensity data for Site 1258 between PETM and ETM-2 reveal the same eccentricity-modulated precession cycles as observed from Leg 208 sites.

XRF core scanning Fe intensity data from four Leg 208 sites are shown in Fig. S1 in the Supplement and given in Tables S1 to S7. All data plotted versus Site 1263 depth are given in Fig. 2 from ETM-2 to Chron C20r. Data for the interval from the PETM to ETM-2 are plotted in Fig. S7 in the Supplement. Due to the large and very detailed data set and the fact that most of the data from PETM to ETM-2 have been published previously, priority for figures in the main paper is on the interval from ETM-2 to Chron C20r.

\subsection{Bulk stable isotope results}

To obtain a complete bulk stable isotope record for Leg 208 sites, the gap in the Site 1263 record was bridged by incorporating bulk data from Site 1265 (Fig. S1a). Bulk stable isotope data from Site 1265 show cyclic variations between 1.6 and $2.2 \%$ and match with overlapping data from Site 1263 (Fig. 2; Westerhold et al., 2015, 217 to $227 \mathrm{rmcd}$ of 1263). As observed previously (Zachos et al., 2010; Littler et al., 2014), lighter bulk $\delta^{13} \mathrm{C}$ data coincide with dark clay-rich intervals with relatively higher XRF Fe intensities at all Leg 208 sites. All bulk and benthic data compiled for this study are presented in Tables S8 to S16.

\subsection{Core image processing and site-to-site correlation}

To correlate and integrate Leg 208 and Site 1258 records, the new software tool CODD (Code for Ocean Drilling Data; Wilkens et al., 2017) was utilized. This tool greatly facilitates handling of large and complex data sets and allows the use of core images for scientific analysis. For all sites in the study, core images and all available data were assembled by 
(a)
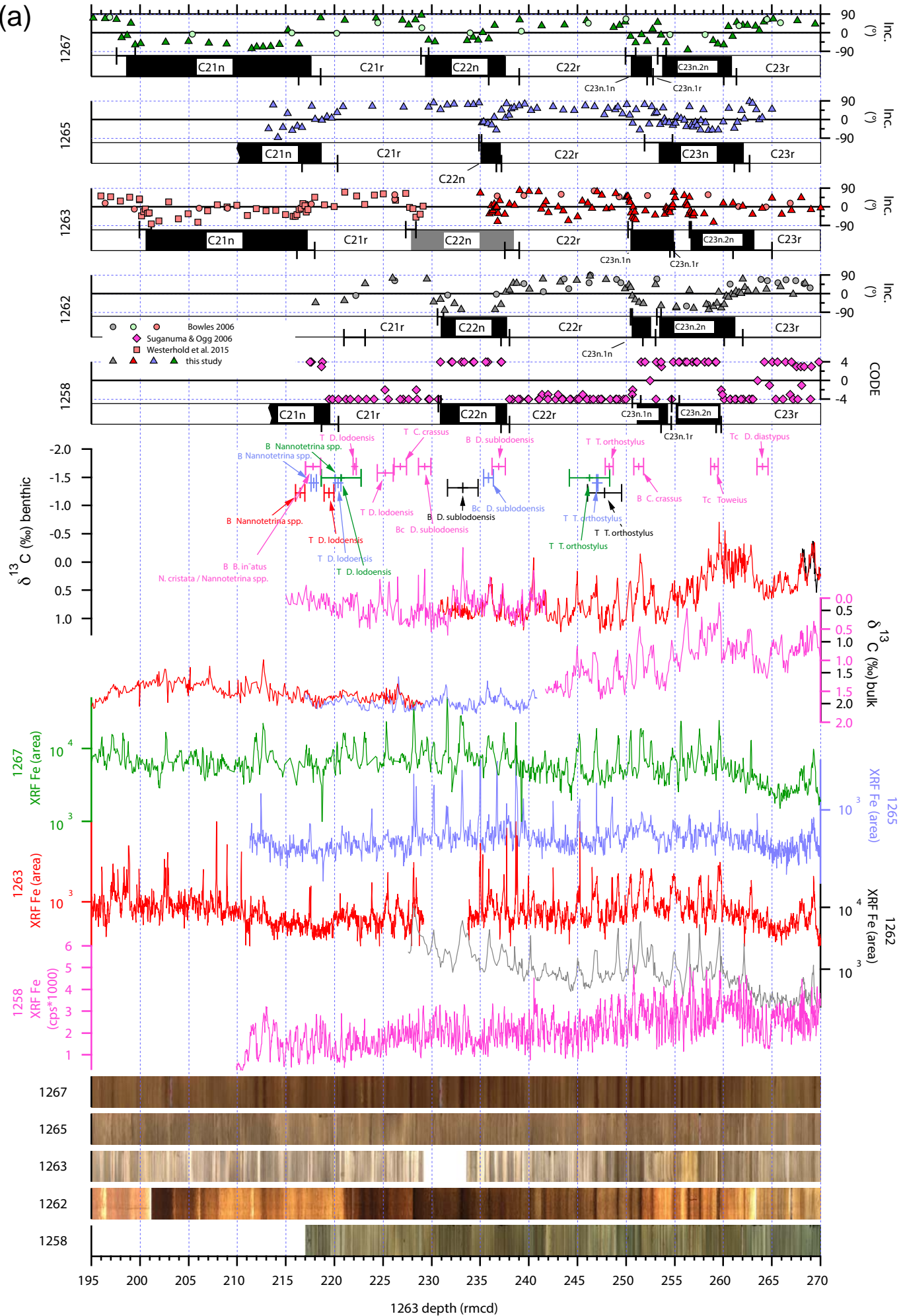

Figure 2. 
(b)
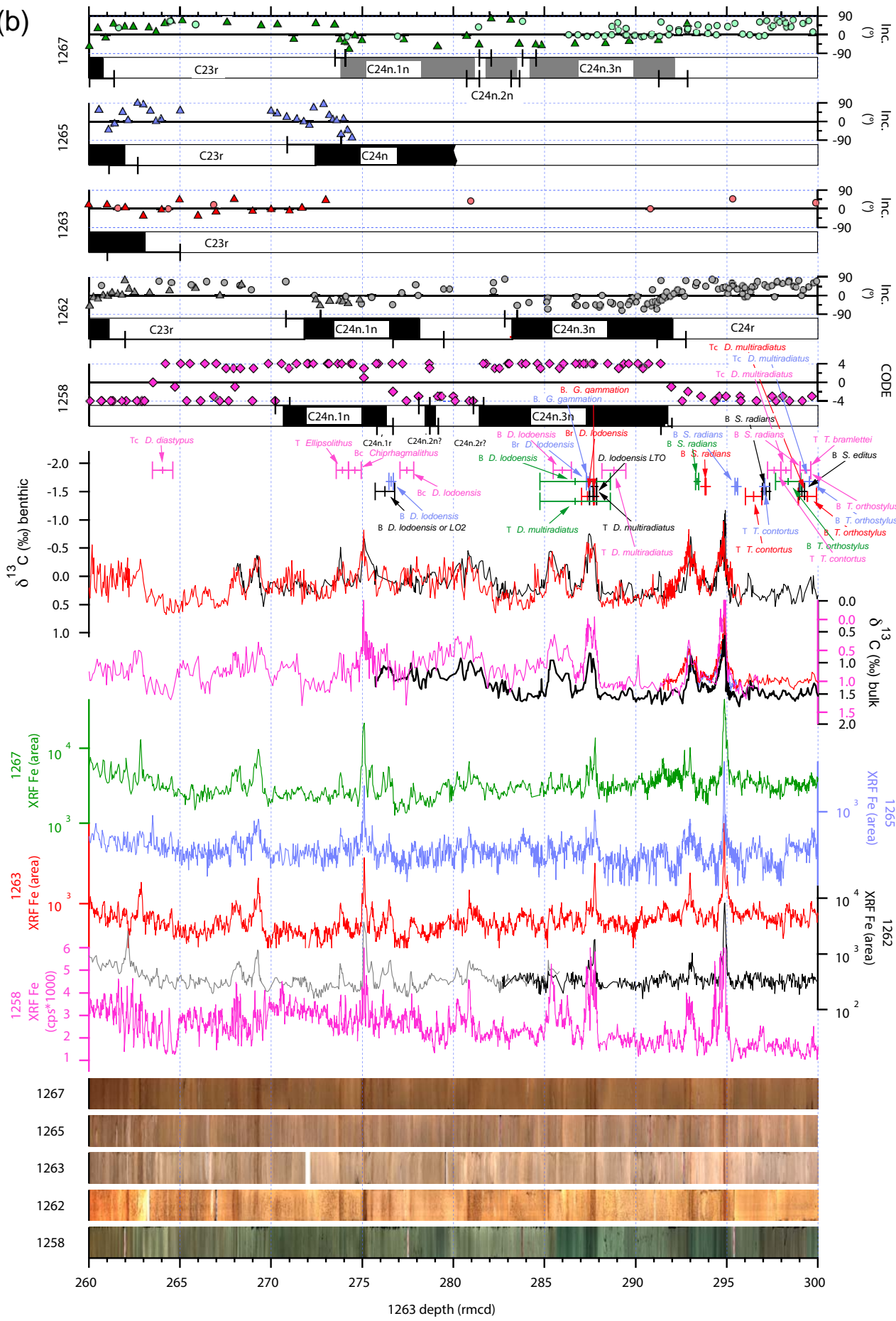

Figure 2. (a) Overview of bio- and magnetostratigraphic data, XRF core scanning Fe intensity data, and core images from ODP Sites $1258,1262,1263,1265$, and 1267 from 195 to $270 \mathrm{rmcd}$ of Site 1263 . The upper five panels show the inclination from characteristic remanent magnetization investigations from this and previous studies with uncertain polarity interpretation in gray. The position of calcareous nannofossil events, including the depth error, is plotted for all sites followed by the compiled benthic and bulk $\delta^{13} \mathrm{C}$ data and XRF core scanning Fe intensities. For a detailed source of data, see the text. Purple: Site 1258; black and grey: Site 1262; red: Site 1263; blue: Site 1265; green: Site 1267. (b) Overview of bio- and magnetostratigraphic data, XRF core scanning Fe intensity data, and core images from ODP Sites 1258, 1262, 1263, 1265, and 1267 from 260 to $300 \mathrm{rmcd}$ of Site 1263. See panel (a). Note that the overview from 300 to $340 \mathrm{rmcd}$ of Site 1263 is in Fig. S7 of the Supplement. 
holes. Then the composite records were cross-checked and assembled. In order to be able to use data generated outside of the splice, all cores were mapped onto the splice using differential stretching and squeezing (Tables S36-S40). Site 1263 was chosen as the reference site to correlate all other sites to because it has the highest sedimentation rates and the most detailed stable isotope data (Lauretano et al., 2015, 2016; McCarren et al., 2008; Stap et al., 2010; Westerhold et al., 2015). XRF Fe and core images primarily guided the correlation between sites (Fig. 2). Stable isotope data are used to assess the correlation between Sites 1258 and 1263 because the XRF Fe data of Site 1258 are dominated by precession cycles and thus difficult to directly correlate to the eccentricity-dominated cycles at Site 1263 (Westerhold and Röhl, 2009). Figure 2 shows the outstanding match between the sites just by visual comparison of the core images. Existing correlations between Leg 208 sites (Röhl et al., 2007; Westerhold et al., 2007; Lauretano et al., 2015) were updated and adjusted if needed. Correlation tie points are provided in Tables S41-S44. The recent correlation between Sites 1262 and 1263 as well as Sites 1263 and 1258 by Lauretano et al. $(2015,2016)$ based on stable isotope data were further refined as well. The primary modifications between Sites 1262 and 1263 were made in a short interval (265 to $267 \mathrm{rmcd}$ ) of Site 1263. The detailed comparison with Site 1265 reveals a gap of about three precession cycles in XRF Fe at 284.40 rmcd at Site 1263 due to a core break (Fig. S6). No additional mismatches were recognized, suggesting that the combined Leg 208 records represent the complete stratigraphic sequence for Walvis Ridge. However, correlation of 1258 to 1263 shows overall good agreement except for the interval from 230 to $235 \mathrm{rmcd}$ of 1263 . Fine-scale comparison of the benthic Site 1258 and bulk Site 1265 stable $\delta^{13} \mathrm{C}$ data show that Leg 208 sediments encompass a regionally condensed interval at $\sim 229-230 \mathrm{rmcd}$ of Site 1263 (Fig. S8). The missing stratigraphic interval spans 300 to $400 \mathrm{kyr}$ as depicted from the Site 1258 benthic record and thus needs to be corrected for in the Site 1263 astronomically tuned age model. This demonstrates the benefits of utilizing multiple records from different regions with robust composite records to establish a highly accurate stratigraphic framework based on orbital tuning for any given interval.

\subsection{Magnetostratigraphic results and interpretation}

Vector analysis according to the method by Kirschvink (1980) without anchoring to the origin of the orthogonal projections was applied to the results of the alternating field demagnetization of NRM to determine the characteristic remanent magnetization (ChRM). The maximum angular deviation (MAD) values were computed, reflecting the quality of individual magnetic component directions. Most of the MAD values are below 10 (Fig. S4, Tables S17-S30). Figure S5 displays the demagnetization characteristics of a sample with reversed polarity from
$\mathrm{C} 22 \mathrm{r}$ and a sample with normal polarity from C22n. As an example of samples with demagnetization behavior with larger scatter (larger MAD), data from a sample at the $\mathrm{C} 22 \mathrm{n}-\mathrm{C} 22 \mathrm{r}$ reversal are plotted in Fig. S5. The larger MADs that can be identified at Leg 208 sites in a few samples are not simply related to the intensity of their remanent magnetization. The median destructive field (MDF) of the NRM demagnetization is comparably low for most of the samples. It ranges from 2.6 to $24 \mathrm{mT}$ (mean $6.1 \pm 3.8 \mathrm{mT}$ ), indicating a magnetically soft overprint in many samples. The interpretation of the ChRM in terms of magnetic polarity is focused on the inclination data, which provide a reliable magnetostratigraphy for most intervals.

Recognition of calcareous nannofossil events allows for the magnetic chrons to be clearly identified from C20r to C24r (Figs. 2 and S4, Tables S26-S30). Raw inclination, declination, and intensity data for each measurement step for Leg 208 sites are given in Tables S17-S20. Magnetostratigraphic interpretation is given in Tables S21-S25. Processed paleomagnetic data from Leg 208 sites, the basis for the magnetostratigraphic interpretation, are provided in Tables S26$\mathrm{S} 30$ for each site. The assignment of error bars, as with all magnetostratigraphic data, is a subjective endeavor. The error bar for Leg 208 data marks the interval in which the inclination shifts from clearly reversed to clearly normal polarity or vice versa. Poorer sample resolution and/or ambiguous or transitional inclination values across a reversal will thus increase the error bar. We did not apply an inclination threshold value to mark a shift in polarity because the reversals occur at different seafloor depths at all sites. Drilling depth and compaction difference between sites might have affected the inclination at each site differently. A much more sharply defined length of error bars could be derived from higher-resolution data (e.g., by analyzing u channels), which is beyond the scope of this study.

Having multiple magnetostratigraphic records from the same region combined with the established high-resolution correlation allows the quality of the paleomagnetic data to be evaluated and inconsistencies to be identified. This, again, is crucial for resolving the $50 \mathrm{Ma}$ discrepancy because a single magnetostratigraphic record from one succession could contain significant unresolved errors. Plotting all Leg 208 ChRM data and the published Site 1258 magnetostratigraphic interpretation against Site 1263 depth immediately shows how consistent but also dynamic the magnetostratigraphy of each site can be (Fig. 2). For example, Chron C22n is clearly too short at Site 1265, which could be related to the condensed interval in this part. Sites 1262 and 1267, however, are consistent with the Site 1258 Chron C22n thickness. At Site 1263 the top of Chron C22n is compromised by drilling disturbance, and the base of Chron C22n is spread over a larger interval than at the other Leg 208 sites. Chron C21n is well captured at Sites 1258, 1263, and 1267, and the base at Site 1265 is also captured well. The top of Chron C23n is consistent between Sites 1258, 1262, 1263, and 1267. The signal 
from Site 1265 is a bit noisy and a clear identification for the top of Chron C23n is difficult. The normal interval labeled as C23n could probably only be C23n.2n. The bottom of Chron C23n is consistent within error at Sites 1262, 1265, and 1267, with Site 1262 giving the best signal. The ChRM of Site 1263 does not provide an interpretable signal below $260 \mathrm{rmcd}$, preventing the identification of the base of C23n and the entire Chron C24n. Clearly, comparison to Site 1258 reveals that Chron $\mathrm{C} 23 \mathrm{n}$ is too short at Site 1258, probably due to the position of the base Chron C23n. Chron C24n can be identified in Leg 208 but has relatively larger error bars than the other chrons. The top of Chron C24n spreads out from $\sim 270$ to $273 \mathrm{rmcd}$ of Site 1263 considering all sites. Taking the overlaps of the error bars into account, the best position for the top and bottom of Chron C $24 n$ is taken from Site 1262. More difficult to determine is the exact position of the reversals in Chrons C24n, C24n.1r, and C24n.2r. No data are available for Sites 1263 and 1265 in this interval. Resolution at Site 1262 is too low to resolve the short reversed chrons. Sites 1267 and 1258 do not give consistent results either. For the moment, the Site 1258 positions are used for the combined magnetostratigraphy but will need future revision. Based on the integration of all data and evaluation of errors, a magnetostratigraphy for the Ypresian was constructed and is given in Table S45. The results of the combined ChRM data on the high-resolution correlation suggest that a magnetostratigraphic interpretation from a single site might contain significant errors that need to be taken into account. Thus, a magnetostratigraphic interpretation from a single site or location can lead to major discrepancies when used as a template for orbital tuning. The new multi-site data already resolve the $50 \mathrm{Ma}$ discrepancy showing that Chron $\mathrm{C} 23 \mathrm{n}$ is too short at Site 1258, causing spreading rates that are too high for the South Atlantic. All of the uncertainties above have been considered while doing the time series analysis and subsequent astronomical calibration for the Ypresian.

\subsection{Calcareous nannofossil events at Sites 1258, 1263, and 1265}

High-resolution correlation between the sites allows us to investigate how reliably calcareous nannofossil datums can be determined, especially over the depth transect of Leg 208. Therefore, key taxa were targeted to be identified at Sites 1263 and 1265 to be compared to the high-resolution work at Site 1262 (Agnini et al., 2007) and low-resolution shipboard data at Site 1267. Biostratigraphic datums are transformed in biochronological data using the integrated bio-, magneto-, and astrocyclostratigraphic age model developed in this study (Tables S31-S35). Age estimations of calcareous nannofossil biohorizons are generally consistent through the Walvis Ridge sites and in agreement with recently published biochronological data (see Agnini et al., 2014, for review). Most of these biohorizons, in particular almost all the bioevents used in previous and more recent calcareous nan- nofossil biozonations, were proven to represent reliable data and powerful tools for highly resolved correlations. A total of 18 biohorizons across the study interval (i.e., decrease in diversity of Fasciculithus spp., B of Rhomboaster spp., the crossover (X) between Fasciculithus spp. and Zyghrablithus bijugatus, the T of Fasciculithus spp., the base of D. diastypus, the T of Tribrachiatus orthostylus, the T of Tribrachiatus contortus, the Tc of Discoaster multiradiatus, the B of Sphenolithus radians, the B of Girgisia gammation, the T of D. multiradiatus, the $\mathrm{Br}$ and $\mathrm{B}$ of Discoaster lodoensis, the B of Chiphragmalithus spp. (circular), the T of T. orthostylus, the $\mathrm{T}$ of D. lodoensis, the B of Chiphragmalithus calathus, and the B of Nannotetrina spp.) were calibrated, and the age estimations are impressively consistent throughout Walvis Ridge sites. Two exceptions are the B of Discoaster sublodoensis, for which the estimates calibrated at different sites show a high degree of uncertainty, and the B of Blackites inflatus, which was not possible to identify because of the absence of this taxon at Walvis Ridge. Other biohorizons, as for instance the B of Coccolithus crassus, are not tested at Walvis Ridge but seem to be promising if data from Demerara Rise and data from the Tethyan realm are compared (Agnini et al., 2014).

Data from ODP Site 1258 were produced to biostratigraphically frame the study succession but these data are also used to investigate the degree of reliability of calcareous nannofossil data over wide areas. In general, the stratigraphic positions as well as the ranking and spacing of the biohorizons detected at this site are in fair agreement with data from Walvis Ridge. The two biochronological data sets presented for Walvis Ridge and Demerara Rise sites showed that the ages calculated for some biohorizons, the B of Rhomboaster spp., the T of Fasciculithus spp., the B of T. orthostylus, the Tc and T of D. multiradiatus, the B of D. lodoensis, the T of T. tribrachiatus, and the B of Nannotetrina spp., are in fact quite close. However, some other results (i.e., the B of $D$. diastypus and the $\mathrm{B}$ of $T$. contortus) are certainly anticipated with respect to the results obtained at Walvis Ridge. These discrepancies are of particular relevance in the midupper part of Chron C24r, though a general slight offset is observable between the two areas. In accordance with the age models developed for the study sites, the anticipation of the first occurrences of some taxa could be explained as related to the warm water preferences of the taxa considered (e.g., Discoaster and Tribrachiatus), but more data are needed to confirm if the diachroneity recorded at Demerara Rise is a general feature of the equatorial latitudes or rather, and more likely, something controlled by local conditions.

\section{Astronomical calibration of the Ypresian}

Time series analysis of early Eocene records that are used here already showed that the dominant cyclicity in multiple proxy records is related to eccentricity. The interval from 
PETM to ETM-2 is dominated by eccentricity-modulated precession cycles that are an impressive recorder of Earth orbital variations through time and the climatic response to them (Lourens et al., 2005; Zachos et al., 2010; Littler et al., 2014). Data from this interval not only allowed the construction of high-precision cyclostratigraphies (Lourens et al., 2005; Westerhold et al., 2007) but also the test of these astrochronologies as well as the theoretical astronomical solutions (Westerhold et al., 2007, 2012; Meyers, 2015). As observed in a compilation of late Paleocene to early Eocene stable isotope data, the $\delta^{13} \mathrm{C}$ variations in both bulk and benthic records from this time show the clear imprint of eccentricity variations, with lighter values occurring in eccentricity maxima (Cramer et al., 2003; Lourens et al., 2005; Zachos et al., 2010; Littler et al., 2014). Hence, bulk and benthic stable isotope data helped to develop astrochronologies from the PETM up to $\sim 49$ Ma spanning Chrons C22r to C24r at Leg 208 sites (Zachos et al., 2010; Littler et al., 2014; Lauretano et al., 2015, 2016). For Site 1258 a first cyclostratigraphic age model based on XRF core scanning Fe intensity was made from ETM-2 to the base of Chron C21n ( $\sim 47 \mathrm{Ma})$ leading to revised estimates for the reversal ages from Chrons C24n to C21n (Westerhold and Röhl, 2009). Because of higher sedimentation rates than observed at Leg 208 sites, cyclicity in the Site 1258 XRF Fe data is mainly precession related, with less-pronounced modulation by eccentricity. Relatively higher sedimentation rates of the order of 3 to $5 \mathrm{~cm} \mathrm{kyr}^{-1}$ lead to pronounced precession cycle recordings, whereas slower sedimentation rates tend to amplify the modulation of precession cycles and thus eccentricity. Compared to sites with a lower sedimentation rate of 1 to $2 \mathrm{~cm} \mathrm{kyr}^{-1}$, the modulation of eccentricity is less pronounced in the XRF data of Site 1258. Both high-resolution bulk and benthic isotope records from Site 1258 revealed that multiple Eocene hyperthermal events exist, presumably forced by eccentricitypaced threshold passing (Sexton et al., 2011; Kirtland Turner et al., 2014). Recently, the eccentricity-driven variations in benthic $\delta^{13} \mathrm{C}$ of sites 1262 and 1263, combined with the bulk $\delta^{13} \mathrm{C}$ data from Site 1258 , were used to construct an astrochronology by tuning the 405 and $100 \mathrm{kyr}$ eccentricity components to the Laskar 2010d orbital solution (Laskar et al., 2011a; Lauretano et al., 2015, 2016). Due to a major shift in $\delta^{13} \mathrm{C}$ at $\sim 260 \mathrm{rmcd}$ of Site 1263 , two tuning options identifying two or three $405 \mathrm{kyr}$ cycles in this interval were proposed. Integration of Site 1258 bulk isotope data and the best fit to the La2010d solution arguably led to a preferred age model with two $405 \mathrm{kyr}$ cycles in the abovementioned interval at Site 1263 (Lauretano et al., 2016).

Based on the previous effort we construct a new consistent age model now spanning the entire Ypresian for sites from Leg 208 and Site 1258 by combining a wealth of available information with new high-resolution data, also making extensive use of the previously untouched spliced core images. Published benthic and bulk stable isotope data were combined for Leg 208 and Site 1258 (Figs. 2 and
S7), plotted at the Site 1263 revised meters composite depth (rmcd) and detrended for long-term trends (Fig. S9). Data have been linearly interpolated at $2 \mathrm{~cm}$ spacing and were then smoothed applying the Igor Pro smooth operation using binomial (Gaussian) smoothing and 30001 points in the smoothing window. Benthic data from Site 1263 located in the disturbed drilling interval were removed from the combined record. The methods for time series analysis are those of Westerhold et al. (2015). Presence of the short and long eccentricity cycle in the isotope data is well documented (Zachos et al., 2010; Littler et al., 2014; Lauretano et al., 2015, 2016). Strong eccentricity-related cyclicity is clearly present in the evolutive wavelet power spectra of both isotope and XRF Fe data (Fig. S10) for the entire Ypresian, applying the magnetostratigraphic interpretation and using either the CK95 (Cande and Kent, 1995) or the GPTS2012 (Vandenberghe et al., 2012) ages for reversals.

We extracted the 405 and $100 \mathrm{kyr}$ component of the data as detected in the evolutive spectra and plotted the filter over the data to investigate where the signal originates. The first-order tuning was done identifying the $405 \mathrm{kyr}$ cycle in all data consistently. The advantage of having the high-resolution XRF Fe data is the ability to detect distinct modulation of the amplitude in the $100 \mathrm{kyr}$ period related to the 405 and $2.4 \mathrm{myr}$ eccentricity cycle modulations. In Fig. S11 in the Supplement, for example, around 242 and $265 \mathrm{rmcd}$ of Site 1263 the XRF Fe data from Site 1263 and 1267 show very low amplitude variations separated by four $405 \mathrm{kyr}$ cycles. If the amplitude modulation (AM) in the data is mainly driven by eccentricity (Zachos et al., 2010; Littler et al., 2014), then these intervals represent the 2.4 myr eccentricity nodes with minor amplitude variations on the $100 \mathrm{kyr}$ level. Identification of the 2.4 myr minima is very important because they function as major tie points for orbital tuning and test for consistency with astronomical solutions (Westerhold et al., 2012, 2015; Zeeden et al., 2013). The starting point for the stable $405 \mathrm{kyr}$ cyclostratigraphy is eccentricity cycle 119 at $48.0 \mathrm{Ma}$, which also represents a 2.4 myr eccentricity minimum (Fig. S11). Records presented here reconnect to astrochronologies that cover the Eocene cyclostratigraphic gap (Westerhold et al., 2015) from Site 1263.

\subsection{How many 405 kyr cycles represent Chron C23?}

Two enigmas had to be solved before a final stable $405 \mathrm{kyr}$ cyclostratigraphy was set up. First, the question of whether two or three $405 \mathrm{kyr}$ cycles are present at Site 1263 in the critical interval from 254 to $265 \mathrm{rmcd}$ of Site 1263 needed to be answered. Second, the question of which orbital solution is appropriate for more detailed orbital tuning on the short eccentricity level needed to be answered. The first issue is complicated by two $\delta^{13} \mathrm{C}$ shifts from 257 to 260 and at $\sim 262$ rmcd of Site 1263 (Fig. 2). Between the shifts, benthic $\delta^{13} \mathrm{C}$ data at Site 1263 do not show a clear eccentricityrelated cyclicity. Instead they reveal higher-frequency cycles 
consistent with higher-frequency cycles in XRF Fe data of Sites 1258 and 1263. One argument to favor the model of two $405 \mathrm{kyr}$ cycles is that it is consistent with uniform sedimentation rate above and below and across this interval (Lauretano et al., 2016). While a reasonable assumption in the absence of other constraints, sedimentation rates at Leg 208 sites do change across the ETM-2 event (see Littler et al., 2014, Fig. 7 therein), decreasing from 1.5 to $0.7 \mathrm{~cm} \mathrm{kyr}^{-1}$ at Site 1262. Using only the new magnetostratigraphy and the CK95 GPTS ages, sedimentation rates at Site 1263 drop from 2.6 to $2.0 \mathrm{~cm} \mathrm{kyr}^{-1}$ across the $\mathrm{C} 24 \mathrm{n} .3 \mathrm{n}-\mathrm{C} 24 \mathrm{r}$ reversal close to ETM-2 and from 1.75 to $1.1 \mathrm{~cm} \mathrm{kyr}^{-1}$ across the $\mathrm{C} 23 \mathrm{n} .2 \mathrm{n}-\mathrm{C} 23 \mathrm{r}$ reversal in the interval between the two $\delta^{13} \mathrm{C}$ shifts (Fig. S13). A decrease in sedimentation rates at both Site 1258 and Site 1263 is very likely to be located in $\mathrm{C} 23 \mathrm{r}$. Time series analysis provides some evidence that cycle thicknesses change between 265 and 254 rmcd of Site 1263 (Fig. S11). Particularly relevant to this question is whether previous astrochronologies for Sites 1258 and 1263 (Westerhold and Röhl, 2009; Lauretano et al., 2016) were based on an underestimate of the duration of Chron $\mathrm{C} 23 \mathrm{n}$ from Site 1258 , which led to the $50 \mathrm{Ma}$ discrepancy, thus making it difficult to determine the correct number of $405 \mathrm{kyr}$ cycles in C23. Comparison to GPTS2012 (Vandenberghe et al., 2012) is compromised by the errors in the radioisotopic calibration points used in $\mathrm{C} 22 \mathrm{n}(48.96 \mathrm{Ma} \pm 0.33)$ and $\mathrm{C} 24 \mathrm{n}(52.93 \mathrm{Ma} \pm 0.23)$. Our new magnetostratigraphy is now more consistent with the width ratio observed in seafloor anomaly profiles from different ocean basins (Cande and Kent, 1995) that was used in GPTS2012.

The eccentricity-modulated precession cycles at ODP Site 1258 can help to test the effects of different numbers of $405 \mathrm{kyr}$ cycles in the interval from 68 to $95 \mathrm{rmcd}$ spanning Chron C23 (Fig. S14). The thicknesses of high-frequency cycles at Site 1258 change from $\sim 45$ to $\sim 32 \mathrm{~cm} \mathrm{cycle}^{-1}$ across 77-82 rmcd at Site 1258 (Westerhold and Röhl, 2009, see Fig. S4 therein). Assuming that the average duration of the cycles is $21 \mathrm{kyr}$, the compression in cycle length translates into a decrease in sedimentation rate from 2.1 to $1.5 \mathrm{~cm} \mathrm{kyr}^{-1}$, as also seen in the new magnetostratigraphy. Applying the Lauretano et al. (2016) age models shows durations for the cycles of 16-24 kyr (two 405 kyr cycles) and 23$35 \mathrm{kyr}$ (three $405 \mathrm{kyr}$ cycles) in this interval (Fig. S14). Due to the constant sedimentation rates in their model between 68 and $92 \mathrm{rmcd}$, the shift in cycle thickness is transformed into overall shortening of the precession cycles, which is rather unrealistic. The option with two $405 \mathrm{kyr}$ cycles seems to best fit the overall duration of $21 \mathrm{kyr}$ for precession cycles and was thus chosen as the preferred age model by Lauretano et al. (2016) for Sites 1258 and 1263. We have developed a new 405 kyr age model (Table S46) based on the time series analysis of multiple high-resolution records that add new tie points in the interval from 68 to $92 \mathrm{rmcd}$ previously not covered. Our new model proposed three rather than two $405 \mathrm{kyr}$ cycles in this interval. As seen in the Site 1258 XRF Fe data, the cycle thickness of the precession-related cycles for the entire interval now show a duration of 21-23 kyr (Fig. S14b). This basic age model also reveals that the long cycles of $\sim 50 \mathrm{~cm}$ length around $80 \mathrm{rmcd}$ represent $41 \mathrm{kyr}$ obliquity cycles.

The principal terms for the precession of the Earth are given by the combination of the fundamental secular frequencies $(g, s)$ of the solar system and the precession frequency $p$ (Laskar, 1993; Hinnov, 2000; Laskar et al., 2004). Two periods dominate the precession: the $\sim 23 \mathrm{kyr}$ period related to Jupiter $(p+g 5)$ and Venus $(p+g 2)$ and the $\sim 19 \mathrm{kyr}$ period related to Mars $(p+g 4)$ and Earth $(p+g 3)$ (Laskar, 1999). Due to the evolution of the precession frequency $p$, the periods have been estimated to be $\sim 22.5$ and $\sim 18.6 \mathrm{kyr}$ (Laskar et al., 2004) 50 million years ago. In the 2.4 myr eccentricity minima, caused by the resonance between Earth and Mars $(g 3-g 4)$, the $\sim 19 \mathrm{kyr}$ period is weak or absent and only the $\sim 23 \mathrm{kyr}$ period is present (Laskar et al., 2004). It has been suggested that the amplitude modulation of the XRF Fe signal of Site 1258 spanning $80-87 \mathrm{rmcd}$ could represent a 2.4 myr eccentricity minimum (Westerhold and Röhl, 2009). If this is correct, the dominating period for precession cycles recorded in the XRF Fe data for the interval from 68 to $92 \mathrm{rmcd}$ should be towards $23 \mathrm{kyr}$ rather than $19 \mathrm{kyr}$, rejecting the two 405 kyr cycle model (Lauretano et al., 2016). Because of a change in phasing between XRF Fe and bulk stable isotope data at $87 \mathrm{rmcd}$, cyclostratigraphy gets more complex at Site 1258. In contrast, Leg 208 sites show a consistent phase relation with decreased $\delta^{13} \mathrm{C}$ values corresponding to higher Fe intensities. Both XRF Fe from Leg 208 and the combined carbon stable isotopes show three $405 \mathrm{kyr}$ cycles in the 265-254 rmcd of Site 1263 interval (S11), and thus we propose a three-cycle model (Fig. S12).

\subsection{Which orbital solution applies best for astronomical tuning?}

\subsubsection{Visual evaluation and determination}

After a stable $405 \mathrm{kyr}$ cyclostratigraphic framework is established, the orbital age model can be refined by tuning the carbon isotope data to an orbital solution on the short eccentricity level. Uncertainties in the ephemeris used to construct the orbital solutions currently limits their accuracy to roughly 48-50 Ma (Laskar et al., 2011a, b; Westerhold et al., 2015). Going beyond $50 \mathrm{Ma}$, the modulation pattern of short eccentricity recorded in the geological data can help to find the correct orbital solution (Laskar et al., 2004, 2011a, b). In particular, knowledge of the exact positions of the very long eccentricity minima, primary anchor for accurate orbital tuning (Shackleton and Crowhurst, 1997; Westerhold et al., 2007; Zeeden et al., 2014), can help to constrain astronomical solutions (Laskar et al., 2004; Westerhold et al., 2012). Beyond an age of $50 \mathrm{Ma}$, the position of the very long eccentricity nodes in available orbital solutions (La2004 - Laskar et al., 



Figure 3. Correlation ties for astronomical calibration from 54.5 to $46 \mathrm{Ma}$. The top panel shows the numerical solutions La2011 (Laskar et al., 2011b) and La2010a-d (Laskar et al., 2011a), including the 405 kyr cycle number counted backwards from today (Wade and Pälike, 2004). Below the Site 1267 core image, which shows the best expressed dark layer pattern of all sites, we plotted the detrended benthic (black) and bulk (grey) combined $\delta^{13} \mathrm{C}$ data as well as XRF Fe intensity records on revised meters composite depth from Site 1263. Areas of low-amplitude modulation in the data are marked in the XRF data for comparison. The blue lines show the tie points for the astronomically tuned age model correlating La2010b eccentricity maxima to lighter (more negative) ${ }^{13} \mathrm{C}$ values. Note the condensed interval in the bulk Site $1265 \delta^{13} \mathrm{C}$ data, which cannot be tuned to the orbital solutions. For detailed discussion, see the text.

2004; La2010 - Laskar et al., 2011a; La2011 - Laskar et al., 2011b) are much more uncertain. Tuning to the La2010 or La2011 solution on the $100 \mathrm{kyr}$ level is possible on the basis of a $405 \mathrm{kyr}$ cyclostratigraphy but should be evaluated with great care. Before a bulk stable isotope record for Site 1258 and a benthic stable isotope record for Site 1263 were generated, only Site 1258 XRF Fe data provided a record sufficient for attempting astronomical tuning of the early Eocene (Westerhold and Röhl, 2009). Here we use a larger and more diverse data set from multiple sites on a stable $405 \mathrm{kyr}$ cyclostratigraphy to test which orbital solution is the most appropriate one for detailed tuning.

The compiled records from the Ypresian, in particular the XRF core scanning Fe intensity data, show prominent minima in eccentricity-related modulation of the data in the intervals 212-220, 240-245, 260-267, 277-285, and 297$307 \mathrm{rmcd}$ of Site 1263 (Figs. 3, S7). Starting with the first common node in the 2.4 myr cycle of La2010 and La2011 at $405 \mathrm{kyr}$ cycles 118 to 119 (47.5-48.0 Ma), we go back in time and compare the position of the very long eccentricity cycle minima to the data amplitude minima of the Ypresian records. Correlating the modulation minima at $212-220 \mathrm{rmcd}$ of Site 1263 to the node at $405 \mathrm{kyr}$ cycles 118 to 119 anchors the records to the astronomically tuned middle to late Eocene timescale (Westerhold et al., 2015). With the application of the stable $405 \mathrm{kyr}$ framework introduced above, the preceding data modulation minima at 240-245, 260-267, 277-285, and $297-307 \mathrm{rmcd}$ of Site 1263 require very long eccentricity minima at $405 \mathrm{kyr}$ cycles $123-124,128-129,132$, and 135-136 (Fig. 3). The first three minima can be observed in the different orbital solutions, suggesting that basically all the solutions back to $52 \mathrm{Ma}$ could be used as target curves for tuning. Beyond $52 \mathrm{Ma}$, only the La2010b and La2010c solutions show a minimum at $405 \mathrm{kyr}$ cycle 132 . Going further back in time to 56-57 Ma, the minimum before ETM-2 (Lourens et al., 2005; Westerhold et al., 2007; Meyers, 2015) and the minimum before the PETM (Westerhold et al., 2007; Zachos et al., 2010; Littler et al., 2014) in the data even match very long eccentricity minima in La2010b and La2010c in $405 \mathrm{kyr}$ cycles $135-136$ (54.3-54.9 Ma) and 140 (56.4 Ma). 


\subsubsection{Statistical evaluation and determination}

Extraction of the AM using statistical methods like those implemented in the astrochron package (Meyers, 2014) or the ENVELOPE (Schulz et al., 1999) routine are important for independently testing the visual recognition of cycle patterns (Hinnov, 2013; Hilgen et al., 2014). AM analysis on XRF core data using the ENVELOPE routine was applied at ODP Sites 1262 (52-60 Ma) and 1258 (47-54 Ma) records in Westerhold et al. (2012) in order to search for the very long eccentricity minima. Meyers (2015) used $a^{*}$ values from ODP Site 1262 between PETM and ETM-2 to test the existing astrochronologies (Lourens et al., 2005; Westerhold et al., 2007). Both methods (Astrochron, ENVELOPE) thus provide sound statistical testing of chronologies at ODP Site 1258 and for Leg 208 sites.

Following the approach of Zeeden et al. (2015), we extracted the short eccentricity cycle $(100 \mathrm{kyr})$ and applied a broad bandpass filter (0.004 to 0.016 cycles kyr ${ }^{-1} ; 250$ $62.5 \mathrm{kyr} \mathrm{cycle}^{-1}$; Tukey window) and subsequently made a Hilbert transform to extract the AM using the Astrochron software package (Meyers, 2015) for data from Sites 1258 and 1263 . We applied the $405 \mathrm{kyr}$ age model as a basic age model (Table S46). The resulting $405 \mathrm{kyr}$ AMs of the XRF Fe intensity data are plotted against the La2004, La2010, and La2011 orbital solutions (Fig. 4). The AMs of the orbital solutions were extracted as described in Westerhold et al. (2012). For Site 1262 we plotted the $405 \mathrm{kyr}$ AM of XRF Fe intensity data using the Option 2 age model of Westerhold et al. (2012), which is almost identical to the updated $405 \mathrm{kyr}$ age model presented here for the 53 to $58 \mathrm{Ma}$ interval. We followed this procedure to demonstrate that similar results can be obtained with different approaches (Astrochron vs. ENVELOPE).

The position of the very long eccentricity minima in the AM of XRF Fe intensity data in the interval from 46 to $59 \mathrm{Ma}$ (blue bars in Fig. 4) best fits with minima in the La2010b and La2010c orbital solutions. In contrast, the minima do not match minima in the La2004 solution, suggesting that this solution is not appropriate for testing geological data in this period of time. The La2010a-d and La2011 solutions fit geological data back to $50 \mathrm{Ma}$. Beyond $50 \mathrm{Ma}$ these solutions diverge (as discussed in Westerhold et al., 2012). Only the La2010b and La2010c solutions exhibit very long eccentricity minima at $\sim 53.3$ and $\sim 54.5 \mathrm{Ma}$. The minimum at $\sim 54.5 \mathrm{Ma}$ is a very prominent feature in the data of the Leg 208 sites that has been intensively discussed (Lourens et al., 2005; Westerhold et al., 2007; Meyers, 2015). The minimum at $\sim 53.3 \mathrm{Ma}$ is also detectable using the statistical methods but can be seen much better by visual inspection of the data (Figs. 2b, 3, and 5).

Quantitative evidence supporting the correct eccentricity node identification can also be derived from the emergence of obliquity cycles in the data at the nodes. Obliquity is not present in the Paleocene and early Eocene (Littler et al.,
2014; Zeebe et al., 2017) of the investigated records. However, Site $1258 \mathrm{Fe}$ intensity data show some obliquity-related cycles at around $80 \mathrm{rmcd}$ (also see Fig. S14) and from 55 to $60 \mathrm{rmcd}$ corresponding to the end of the very long eccentricity node at $52 \mathrm{Ma}$ and the beginning of the very long eccentricity node at $50 \mathrm{Ma}$. At another potential node ( $48 \mathrm{Ma}$ ), Site $1258 \mathrm{Fe}$ data do not clearly exhibit obliquity cycles but rather low-amplitude modulations of precession-related cyclicity (Westerhold and Röhl, 2009, see Fig. 9 therein). Considering all these observations, they provide some independent evidence for the existence of eccentricity nodes at 50 and $52 \mathrm{Ma}$. The nodes at $\sim 53.3$ and $\sim 54.5 \mathrm{Ma}$ show no prominent obliquity cycles in the Fe records, as already discussed above and in Littler et al. (2014).

Based on our observations and the statistical analysis (Hinnov, 2013; Hilgen et al., 2014), we decided to fine-tune the records to the La2010b orbital solution (Fig. 5). It has to be noted here that there is hardly any difference between the La2010b and La2010c solution in the Ypresian from 46$56 \mathrm{Ma}$. Therefore, it does not matter if La2010b or La2010c is chosen as a target curve. Consequences of the match between orbital solutions and the geological data as well as the implications of the new age model for magnetostratigraphy need to be discussed. The tie points for the tuned short eccentricity age model are given in Table S47.

\subsubsection{Potential distortion by nonlinear response of the climate system}

Nonlinear response of climate is critical in the Ypresian. Multiple carbon cycle perturbations are documented as negative carbon isotope excursions (CIEs) and the dissolution of carbonates at the seafloor, both pointing to massive releases of ${ }^{13} \mathrm{C}$-depleted carbon to the ocean-atmosphere system. Associated warming has led to the term hyperthermals for these events. If the ${ }^{13} \mathrm{C}$-depleted carbon caused the warming and all events were triggered by carbon from the same reservoir, the magnitude of the CIEs scaled to the amount of carbon injected (Pagani et al., 2006). Because the residence time of carbon is of the order of $100 \mathrm{kyr}$ (Broecker and Peng, 1982), the events will influence the amplitude of the bulk and benthic stable carbon isotope data and thus any AM analysis of early Eocene records. Additionally, the added carbon also leads to dissolution of carbonates at the seafloor, increasing the relative amount of non-carbonate material in the sediment (as detected by higher XRF Fe values). This will influence the statistical and visual recognition of cyclicity as discussed above. Modeling suggests that hyperthermals, except for the Paleocene-Eocene Thermal Maximum (PETM), could be paced by eccentricity forcing of the carbon cycle with the amplitudes of the events being partly driven by the eccentricity amplitude itself (Kirtland Turner et al., 2014). Variations in carbon isotope data do correspond to AM in the short-eccentricity cycle. In particular, the very long eccentricity minima are expressed as an interval of very low AM 

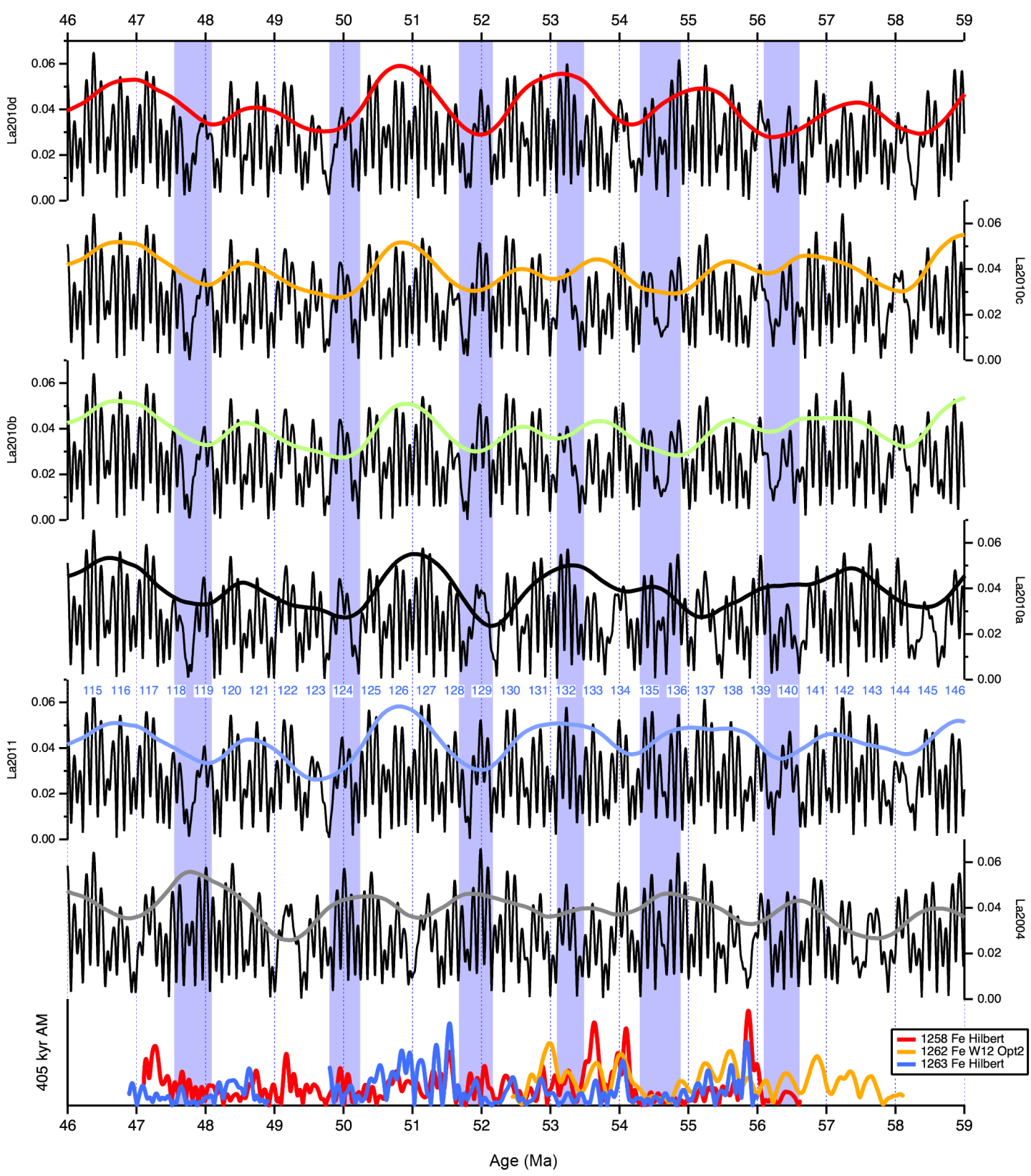

Figure 4. Comparison of the amplitude modulation (AM) of the short eccentricity cycle between the La2004, La2010, and La2011 orbital solutions and Fe intensity data from ODP Sites 1258 (red), 1262 (orange), and 1263 (blue). For the orbital solutions we also plotted the $405 \mathrm{kyr}$ AM. The short eccentricity AM of Sites 1258, 1262, and $1263 \mathrm{Fe}$ intensity data are plotted on the 405 kyr scale model. The very long eccentricity minima are highlighted by light blue bars in the orbital solutions and the Fe intensity data. Statistical and visual recognition of the cycle pattern suggests that the La2010b and La2010c solutions are most consistent with the geological data.

in the benthic carbon isotope data. Almost all hyperthermal events occur outside the very long eccentricity minima. Only very minor excursions at $\mathrm{C} 21 \mathrm{r} 5, \mathrm{C} 22 \mathrm{r} 5$, and $\mathrm{C} 23 \mathrm{n} .2 \mathrm{nH} 1 \mathrm{co}-$ incide with these nodes, but with comparatively reduced CIE than hyperthermals, suggesting that these might not be hyperthermals in the end. Hyperthermal layers are very well documented in the XRF data by prominent peaks due to dissolution of carbonate and since larger CIEs are characterized by higher XRF Fe peaks. This tends to exaggerate the AM in the statistical analysis (Fig. 4). Hyperthermal events could be interpreted as amplifiers of the eccentricity amplitude, with a bias toward higher amplitudes. Because the focus in identifying the best fit astronomical solution lies on the very long eccentricity minima, this ensures that the distortion by hyperthermal events does not significantly alter the results of our study. 


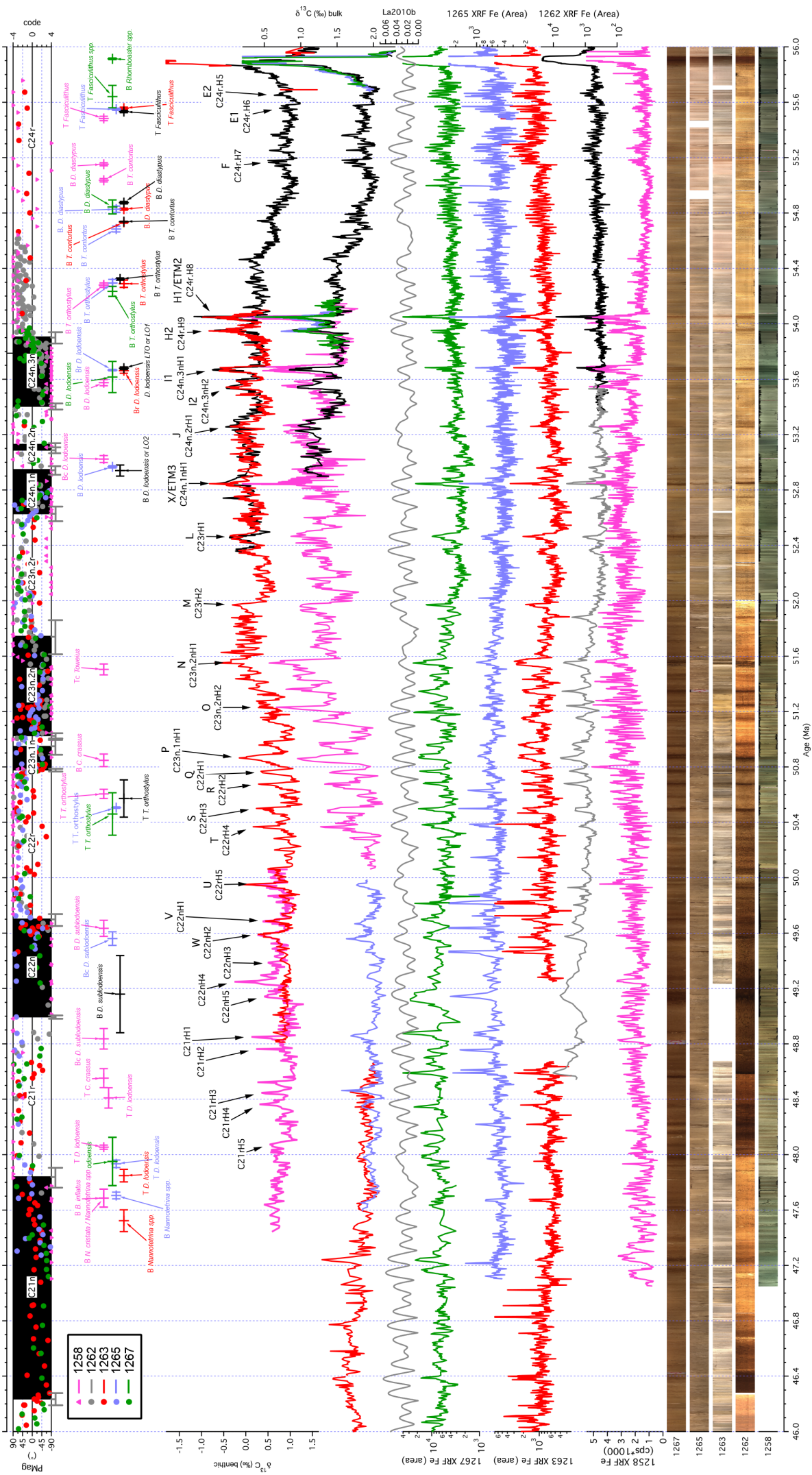

Figure 5. Bio- and magnetostratigraphic data, benthic and bulk stable isotopes, XRF core scanning Fe intensities, and core images for the new astrochronology for the Ypresian stage. Inclination data from ChRM analysis of each site from Leg 208 are shown. For Site 1258 the results of Suganuma and Ogg (2006) are given as a code between -4 and 4 , with negative values indicating reversed polarity. The final synthesized magnetostratigraphy (Table S45) includes the error for the reversals (bars). Also shown is the La2010b (Laskar et al., 2011a) orbital solution by the central grey line. Note the extremely good match between orbital solution and amplitude modulation in the various XRF and stable isotope records. Hyperthermal events have been labeled according to Table 3. 


\section{Discussion}

We have established the first complete astrochronology for the entire Ypresian stage (YATS), compiling, integrating, and synthesizing geochemical and bio- and magnetostratigraphic records at unprecedented precision. The result is a complex stratigraphy that can function as a reference, allowing synchronization of paleoclimate records essential to understanding cause and consequences of events in the early Eocene.

\subsection{Geological evidence for chaotic behavior of the solar system in the Ypresian?}

Just recently the first geologic evidence confirming the chaotic behavior of the solar system through the identification of a chaotic resonance transition during the Coniacian ( $~ 85-87 \mathrm{Ma}$ ) was reported (Ma et al., 2017). Similarly, the new records presented here appear to provide additional observational confirmation of the past chaotic evolution of the solar system, but as recently as $\sim 52 \mathrm{Ma}$. Long-term simulations of orbital motions to study the stability of the solar system propose a chaotic rather than quasiperiodic pattern of motion in the solar system (Laskar, 1989; Laskar et al., 2004, 2011a). A macroscopic feature displaying the chaotic diffusion of the planetary orbits identifiable in geological records is the transition from libration to circulation in the resonant argument related to $\Theta=(s 4-s 3)-2(g 4-g 3)$, the combination of angles in the precession motion of the orbits of Earth and Mars (Laskar et al., 2004, 2011a; Pälike et al., 2004; see Westerhold et al., 2015, chap. 5.3 for detailed discussion). One needs to extract the AM of both obliquity and precession in a geological data set in order to detect the transition from libration to circulation (Laskar, 1999), which is almost impossible, requiring a record that is influenced (or driven) by both high-latitude and low-latitude processes (Laskar et al., 2011a). Obliquity AM could be extracted from benthic $\delta_{18} \mathrm{O}$ records, for example, if deep-sea temperature variations are continuously affected by obliquity. This is not the case for the Paleocene and early Eocene (Littler et al., 2014; Zeebe et al., 2017). Thus, investigation of the AM of obliquity is difficult with the currently available records. Laskar et al. (2011a) recommended searching for a modulation of the $g 4-g 3$ period, the $\sim 2.4$ myr eccentricity modulation. The transition from libration to circulation should be visible by a switch from a $\sim 2.4$ myr period to a $\sim 1.2$ myr period in the modulation of eccentricity and climatic precession (Laskar, 1999; Laskar et al., 2004, 2011a; Pälike et al., 2004; Ma et al., 2017). Importantly, this could be transient with a switch back to $\sim 2.4$ myr shortly after (Laskar, 1999).

With the new cyclostratigraphy based on the stable $405 \mathrm{kyr}$ eccentricity cycle for the Ypresian, we can test if this switch is present in the observations. Previously, the identification of the very long eccentricity cycle in geological data for the Ypresian used the XRF Fe intensities from Sites 1258 and 1262 only (Westerhold et al., 2007; Westerhold and
Röhl, 2009). The multiple proxy data now provide a much clearer picture, as described in Sect. 4.2, and show a very good match between geological data and the La2010b and La2010c numerical orbital solutions (Laskar et al., 2011a) for the Ypresian. The important feature shared between data and models is the position of the very long eccentricity minima expressed as areas of low-amplitude modulation in the data itself (Figs. 3, 4, 5). In the La2010b and La2010c solutions, the transition from libration to circulation occurs at $\sim 52 \mathrm{Ma}$ (Laskar et al., 2011a). Comparing orbital solutions with geological data indicates that the transition from libration to circulation occurred between 52 and $55 \mathrm{Ma}$. The AM minima in the data from 47 to $52 \mathrm{Ma}$ are spaced at 2 to $2.4 \mathrm{myr}$ (Figs. 4, 5), from 52 to $55 \mathrm{Ma}$ they are spaced at roughly $1.2 \mathrm{myr}$, and after $55 \mathrm{Ma}$ the spacing is $\sim 2.4 \mathrm{myr}$.

None of the available orbital solutions perfectly fit the geological data. However, it is important that we isolated the transition in the data, which is also present in the La2010b and La2010c solutions. The short eccentricity cycle pattern both in the solutions and the geological data will not match perfectly beyond $50 \mathrm{Ma}$ when the uncertainty in the solutions increase (as discussed in Westerhold et al., 2012). Still, the geological data and La2010b/c solutions are very similar from 53.5 Ma to the PETM. In the interval from 51 to $52 \mathrm{Ma}$, the most difficult part to tune in the Ypresian, multiple hyperthermal events and the shift in carbon isotope data make a direct comparison much more difficult. It has to be noted here that the eccentricity solutions from La2010b/c might not be completely reliable in this interval. Despite the uncertainties, we provide a tuned age model to $\mathrm{La} 2010 \mathrm{~b} / \mathrm{c}$ because the match in the $53.5 \mathrm{Ma}$ to the PETM interval is good enough to do so. If in doubt, the provided $405 \mathrm{kyr}$ age model can still be used.

The point in time when the transition occurs in the numerical solutions is sensitive to the initial conditions of the planetary ephemeris used for back calculation of the planetary motions. The initial conditions depend on the accuracy of the observational data used to make a least squares fit of the model to the data. The La2010b/c solutions used the INPOP08 Ephemeris (Fienga et al., 2009; Laskar et al., 2011a). In contrast, the La2010d solution used the INPOP06 Ephemeris (Fienga et al., 2008) and the La2011 solution the INPOP10a ephemeris (Fienga et al., 2011). The very similar long-term behavior of INPOP06 and INPOP10a lead to the conclusion that these ephemerides are more stable than INPOP08 (Laskar et al., 2011b; Westerhold et al., 2012). Although the INPOP10a ephemeris is considered to be more accurate than INPOP08 (Fienga et al., 2011), the geological data provide evidence that the latter is closer to reality. Identifying the transition from libration to circulation at $\sim 52 \mathrm{Ma}$ in sediment archives is of great importance, not only because it supports the theory on the chaotic nature of the solar system (Laskar, 1989), but it also provides a benchmark to set the conditions for the gravitational model of the solar system (Laskar et al., 2004). It has to be noted that from an 
Table 1. Comparison of magnetochron boundary ages in millions of years.

\begin{tabular}{|c|c|c|c|c|c|c|c|c|c|}
\hline \multirow[t]{2}{*}{ Chron } & \multicolumn{3}{|c|}{ Standard GPTS } & \multicolumn{5}{|c|}{ Tuned $^{*}$ GPTS } & \multirow{2}{*}{$\begin{array}{c}\text { This study }^{\dagger} \\
\text { Leg208 } \\
\text { Site1258 }\end{array}$} \\
\hline & CK95 & $\begin{array}{c}\text { GPTS } \\
2004\end{array}$ & $\begin{array}{c}\text { GPTS } \\
2012\end{array}$ & $\begin{array}{l}\text { PEAT } \\
\text { Sites }^{\#}\end{array}$ & $\begin{array}{c}\text { Contessa } \\
\text { Hyw }\end{array}$ & $\begin{array}{l}\text { ODP Site } \\
1260\end{array}$ & $\begin{array}{c}\text { ODP Site } \\
1258 \text { opt.2 }\end{array}$ & $\begin{array}{c}\text { ODP Site } \\
1263\end{array}$ & \\
\hline C18n.2n (o) & 40.130 & 39.464 & 40.145 & $40.076 \pm 0.005$ & 40.120 & & & & \\
\hline $\mathrm{C} 19 \mathrm{n}(\mathrm{y})$ & 41.257 & 40.439 & 41.154 & $41.075 \pm 0.007$ & 41.250 & $41.061 \pm 0.009$ & & $41.030 \pm 0.013$ & \\
\hline C19n (o) & 41.521 & 40.671 & 41.390 & $41.306 \pm 0.005$ & 41.510 & $41.261 \pm 0.004$ & & $41.180 \pm 0.011$ & \\
\hline $\mathrm{C} 20 \mathrm{n}(\mathrm{y})$ & 42.536 & 41.590 & 42.301 & $42.188 \pm 0.015$ & 42.540 & $42.152 \pm 0.007$ & & $42.107 \pm 0.013$ & $42.196 \pm 0.013$ \\
\hline C20n (o) & 43.789 & 42.774 & 43.432 & & 43.790 & $43.449 \pm 0.018$ & & $43.517 \pm 0.011$ & $43.507 \pm 0.011$ \\
\hline $\mathrm{C} 2 \ln (\mathrm{y})$ & 46.264 & 45.346 & 45.724 & & 46.310 & & & $46.151 \pm 0.009$ & $46.235 \pm 0.044$ \\
\hline $\mathrm{C} 2 \ln (\mathrm{o})$ & 47.906 & 47.235 & 47.349 & & & & $47.723 \pm 0.118$ & $47.575 \pm 0.018$ & $47.834 \pm 0.072$ \\
\hline $\mathrm{C} 22 \mathrm{n}(\mathrm{y})$ & 49.037 & 48.599 & 48.566 & & & & $48.954 \pm 0.016$ & & $48.994 \pm 0.012$ \\
\hline $\mathrm{C} 22 \mathrm{n}(\mathrm{o})$ & 49.714 & 49.427 & 49.344 & & & & $49.593 \pm 0.042$ & & $49.695 \pm 0.043$ \\
\hline $\mathrm{C} 23 \mathrm{n} . \ln (\mathrm{y})$ & 50.778 & 50.730 & 50.628 & & & & $51.051 \pm 0.021$ & & $50.777 \pm 0.010$ \\
\hline $\mathrm{C} 23 \mathrm{n} . \ln (\mathrm{o})$ & 50.946 & 50.932 & 50.835 & & & & $51.273 \pm 0.039$ & & $50.942 \pm 0.054$ \\
\hline $\mathrm{C} 23 \mathrm{n} .2 \mathrm{n}(\mathrm{y})$ & 51.047 & 51.057 & 50.961 & & & & $51.344 \pm 0.032$ & & $51.025 \pm 0.019$ \\
\hline C23n.2n (o) & 51.743 & 51.901 & 51.833 & & & & $51.721 \pm 0.023$ & & $51.737 \pm 0.123$ \\
\hline C24n.1n (y) & 52.364 & 52.648 & 52.620 & & & & $52.525 \pm 0.023$ & & $52.628 \pm 0.053$ \\
\hline $\mathrm{C} 24 \mathrm{n} . \ln (\mathrm{o})$ & 52.663 & 53.004 & 53.074 & & & & $52.915 \pm 0.029$ & & $52.941 \pm 0.031$ \\
\hline $\mathrm{C} 24 \mathrm{n} .2 \mathrm{n}(\mathrm{y})$ & 52.757 & 53.116 & 53.199 & & & & 53.037 & & $53.087 \pm 0.021$ \\
\hline $\mathrm{C} 24 \mathrm{n} .2 \mathrm{n}(\mathrm{o})$ & 52.801 & 53.167 & 53.274 & & & & 53.111 & & $53.123 \pm 0.015$ \\
\hline $\mathrm{C} 24 \mathrm{n} .3 \mathrm{n}(\mathrm{y})$ & 52.903 & 53.286 & 53.416 & & & & $53.249 \pm 0.017$ & & $53.403 \pm 0.022$ \\
\hline $\mathrm{C} 24 \mathrm{n} .3 \mathrm{n}(\mathrm{o})$ & 53.347 & 53.808 & 53.983 & & & & $53.806 \pm 0.020$ & & $53.899 \pm 0.041$ \\
\hline
\end{tabular}

astronomer's point of view the La2010b and La2010c solutions are considered less reliable because they used a less stable ephemeris (Fienga et al., 2011; Laskar et al., 2011a). The same is true for the Laskar et al. (2004) solution, but the Niobrara data suggest a better fit to geological data than the nominal models of La2010d and La2011 (Ma et al., 2017). Clearly, the La2004 solution is not consistent with the geological data from 46 to $58 \mathrm{Ma}$ (Fig. 4), with implications for arguments of Ma et al. (2017). In fact, all eccentricity AMs from the different theoretical astronomical solutions show a different and to some extent unusual behavior between 52 and $54 \mathrm{Ma}$ (Fig. S15). Our new findings should motivate efforts to further explore the differences in the ephemerides.

Our results support the application of La2010b or La2010c solutions for eccentricity to construct astronomical age models back to $60 \mathrm{Ma}$. Beyond $60 \mathrm{Ma}$ an accurate solution for eccentricity is not possible at the moment (Laskar et al., $2011 \mathrm{~b}$ ), but the stable $405 \mathrm{kyr}$ cycles will still provide a good target to establish astrochronologies (Laskar et al., 2004, 2011a, b). Here again, the geological data should be examined to find the very long eccentricity minima in very early Cenozoic and Mesozoic strata (Meyers, 2015) and provide a landmark for developing more precise orbital solutions.

\subsection{Solving the 50 Ma discrepancy in seafloor spreading rates}

Combining the new astrochronology with the revised magnetostratigraphy for the Ypresian allows us to consider the significance of the abrupt global increase in spreading rates in Chron C23n.2n, which is also known as the 50 Ma dis- crepancy on the Paleogene timescale (Vandenberghe et al., 2012). The unusual peak in spreading rates in the South Atlantic (Fig. 6a) is independent of the age model used for the magnetostratigraphic interpretation of Site 1258 (Westerhold and Röhl, 2009; Westerhold et al., 2012; Lauretano et al., 2016). The new multi-site magnetostratigraphic data from Leg 208 sites reveal that Chron C23n is too short in the Site 1258 magnetostratigraphic interpretation (Suganuma and Ogg, 2006) and the likely reason for the computed peak in spreading rates. Application of the tuned age model to the integrated magnetostratigraphy results in a moderate but distinct jump in spreading rates at the $\mathrm{C} 23 \mathrm{n} .2 \mathrm{n}-\mathrm{C} 23 \mathrm{r}$ reversal from 12 to $19 \mathrm{~km} \mathrm{myr}^{-1}$. The exact age of the increase cannot be precisely located using the reversal pattern only, but it probably occurred somewhere in $\mathrm{C} 23 \mathrm{r}$ or $\mathrm{C} 23 \mathrm{n}$. $2 \mathrm{n}$ between 51.0 and $52.5 \mathrm{Ma}$. Interestingly, this timing is synchronous with a major reorganization of the plate-mantle system (Whittaker et al., 2007), the subduction initiation of the Izu-Bonin-Mariana arc (Ishizuka et al., 2011), and the bend in the Hawaii-Emperor seamount chain (O'Connor et al., 2013). Changes in spreading rates in the interval from 51.0 to $52.5 \mathrm{Ma}$ thus seem to be a global phenomenon pointing to a major common driving mechanism.

Astronomical calibration of the refined magnetostratigraphy in the marine records resulted in an improved GPTS for the Ypresian (Fig. 6b, Table 1). Duration of polarity zones are now consistent with the reversal thickness relationships observed in the South Atlantic and within error for the mean width of magnetic anomalies as published in Table 4 of Cande and Kent (1992) (Tables 2 and S46). The improved magnetostratigraphy shows a $376 \mathrm{kyr}$ shorter du- 
(a)

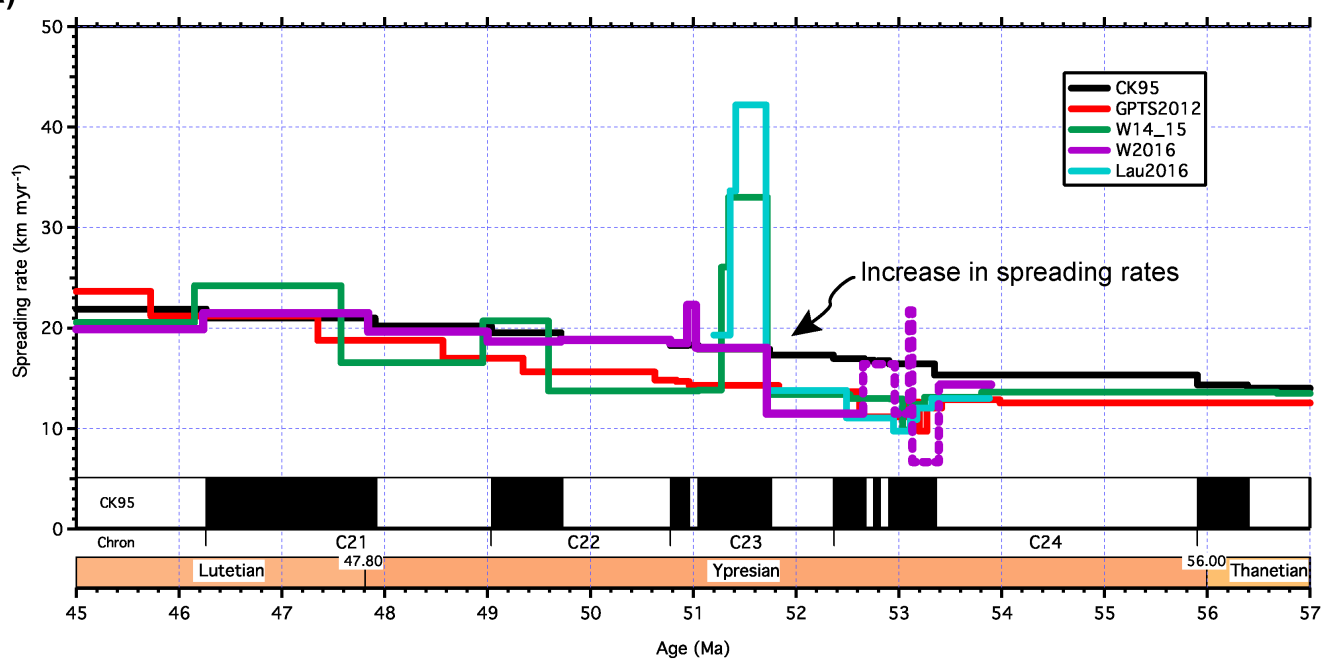

(b)

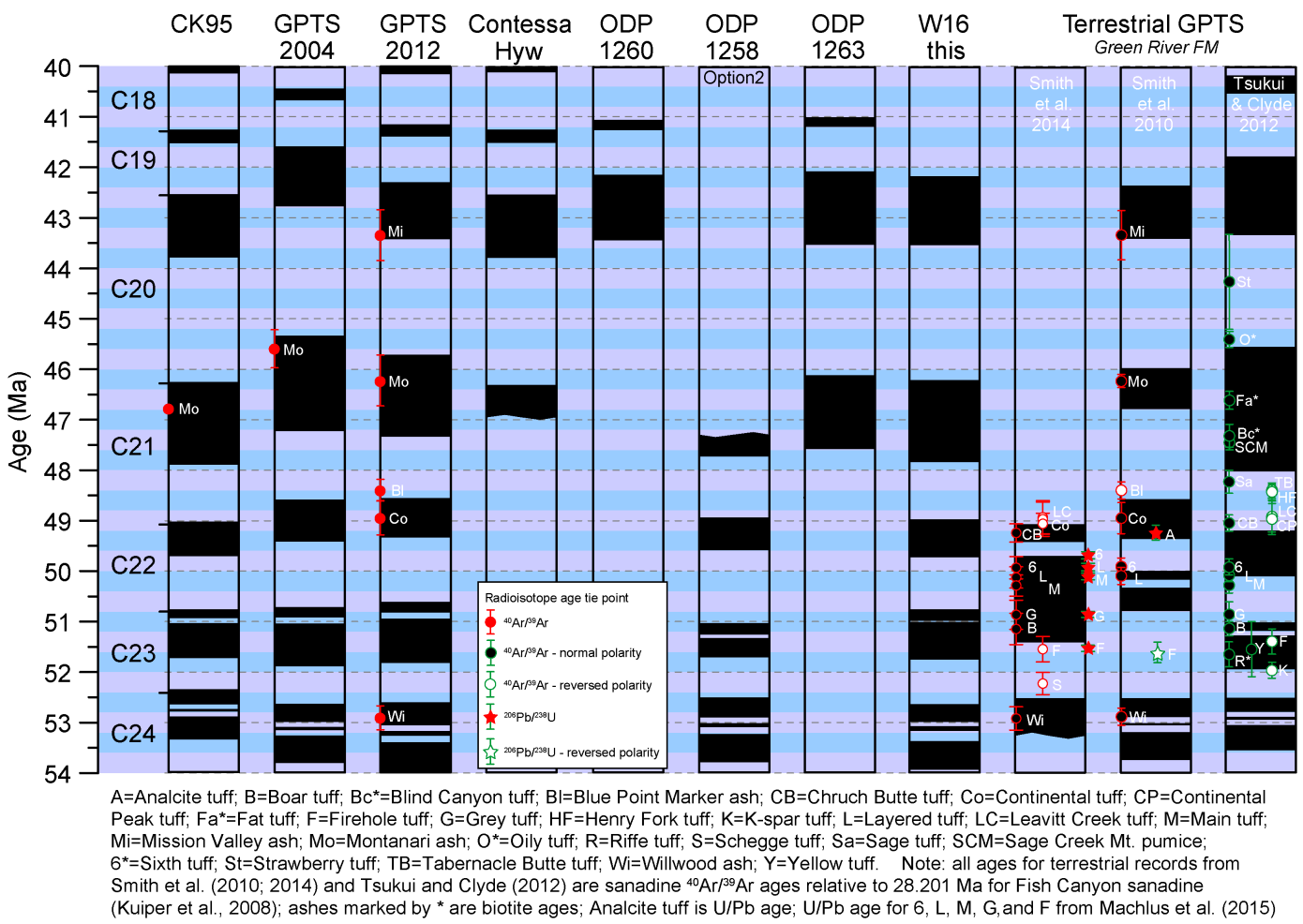

Figure 6. (a) Comparison of calculated spreading rates for the synthetic South Atlantic profile of Cande and Kent (1992) based on the age model of Cande and Kent (1995), GPTS2012 (Vandenberghe et al., 2012), Westerhold et al. (2015), Lauretano et al. (2016), and this study (W2016). The GPTS of CK95 is also plotted for reference. Note the increase in spreading rates in the South Atlantic at $\sim 52$ Ma based on the new GPTS presented in this study. (b) Geomagnetic polarity timescale of CK95 (Cande and Kent, 1995), GPTS2004 (Ogg and Smith, 2004), and GPTS2012 (Ogg, 2012; Vandenberghe et al., 2012) compared to astronomical calibrations of magnetochrons from Contessa Highway (Jovane et al., 2010), Site 1260 (Westerhold and Röhl, 2013), Site 1258 (Westerhold and Röhl, 2009; Westerhold et al., 2012), Site 1263 (Westerhold et al., 2015), and the new Ypresian GPTS (this study, W16) from 40 to 54 Ma. Terrestrial calibration of the GPTS from the Green River Formation (Smith et al., 2010, 2014; Tsukui and Clyde, 2012) is also shown. Small red dots with error bars mark the radioisotopic calibration points used for CK95, GPTS2004, GPTS2012, and Smith et al. (2010); green circles show calibration points for the terrestrial sections used by Tsukui and Clyde (2012). The overview demonstrates the now consistent Eocene GPTS from 30 to 54 Ma from ODP stratigraphic data and the discrepancy in the terrestrial GPTS. See text for discussion. 
Table 2. Comparison of magnetochron boundary durations in millions of years.

\begin{tabular}{|c|c|c|c|c|c|c|c|c|c|}
\hline \multirow{2}{*}{ Chron } & \multicolumn{3}{|c|}{ Standard GPTS } & \multicolumn{5}{|c|}{ Tuned" GPTS } & \multirow{2}{*}{$\begin{array}{c}\text { This study }{ }^{\dagger} \\
\text { Leg208 } \\
\text { Site1258 }\end{array}$} \\
\hline & CK95 & $\begin{array}{c}\text { GPTS } \\
2004\end{array}$ & $\begin{array}{c}\text { GPTS } \\
2012\end{array}$ & $\begin{array}{l}\text { PEAT } \\
\text { Sites }^{\#}\end{array}$ & $\begin{array}{c}\text { Contessa } \\
\text { Hyw }\end{array}$ & $\begin{array}{c}\text { ODP Site } \\
1260\end{array}$ & $\begin{array}{c}\text { ODP Site } \\
1258 \text { opt.2 }\end{array}$ & $\begin{array}{c}\text { ODP Site } \\
1263\end{array}$ & \\
\hline C18n.2r & 1.127 & 0.975 & 1.009 & $0.999 \pm 0.012$ & & & & & \\
\hline $\mathrm{C} 19 \mathrm{n}$ & 0.264 & 0.232 & 0.236 & $0.231 \pm 0.012$ & 0.260 & $0.200 \pm 0.007$ & & $0.150 \pm 0.024$ & \\
\hline $\mathrm{C} 19 \mathrm{r}$ & 1.015 & 0.919 & 0.911 & $0.882 \pm 0.020$ & 1.030 & $0.891 \pm 0.006$ & & $0.927 \pm 0.024$ & \\
\hline $\mathrm{C} 20 \mathrm{n}$ & 1.253 & 1.184 & 1.131 & & 1.250 & $1.297 \pm 0.013$ & & $1.410 \pm 0.024$ & $1.311 \pm 0.011$ \\
\hline $\mathrm{C} 20 \mathrm{r}$ & 2.475 & 2.572 & 2.292 & & 2.520 & & & $2.634 \pm 0.020$ & $2.727 \pm 0.044$ \\
\hline $\mathrm{C} 21 \mathrm{n}$ & 1.642 & 1.889 & 1.625 & & & & & $1.424 \pm 0.027$ & $1.599 \pm 0.072$ \\
\hline $\mathrm{C} 21 \mathrm{r}$ & 1.131 & 1.364 & 1.217 & & & & $1.231 \pm 0.134$ & & $1.161 \pm 0.012$ \\
\hline $\mathrm{C} 22 \mathrm{n}$ & 0.677 & 0.828 & 0.778 & & & & $0.639 \pm 0.058$ & & $0.700 \pm 0.043$ \\
\hline $\mathrm{C} 22 \mathrm{r}$ & 1.064 & 1.303 & 1.284 & & & & $1.458 \pm 0.063$ & & $1.082 \pm 0.010$ \\
\hline C23n.1n & 0.168 & 0.202 & 0.207 & & & & $0.222 \pm 0.060$ & & $0.166 \pm 0.054$ \\
\hline C23n.1r & 0.101 & 0.125 & 0.126 & & & & $0.071 \pm 0.071$ & & $0.083 \pm 0.019$ \\
\hline $\mathrm{C} 23 \mathrm{n} .2 \mathrm{n}$ & 0.696 & 0.844 & 0.872 & & & & $0.377 \pm 0.055$ & & $0.712 \pm 0.123$ \\
\hline $\mathrm{C} 23 \mathrm{n}$ & 0.965 & 1.205 & 1.200 & & & & $0.670 \pm 0.044$ & & $0.961 \pm 0.133$ \\
\hline $\mathrm{C} 23 \mathrm{r}$ & 0.621 & 0.747 & 0.787 & & & & $0.804 \pm 0.046$ & & $0.890 \pm 0.053$ \\
\hline C24n.1n & 0.299 & 0.356 & 0.454 & & & & $0.390 \pm 0.052$ & & $0.314 \pm 0.031$ \\
\hline C24n.1r & 0.094 & 0.112 & 0.125 & & & & 0.122 & & $0.145 \pm 0.021$ \\
\hline $\mathrm{C} 24 \mathrm{n} .2 \mathrm{n}$ & 0.044 & 0.051 & 0.075 & & & & 0.074 & & $0.036 \pm 0.015$ \\
\hline $\mathrm{C} 24 \mathrm{n} .2 \mathrm{r}$ & 0.102 & 0.119 & 0.142 & & & & 0.138 & & $0.280 \pm 0.022$ \\
\hline $\mathrm{C} 24 \mathrm{n} .3 \mathrm{n}$ & 0.444 & 0.522 & 0.567 & & & & $0.557 \pm 0.037$ & & $0.496 \pm 0.041$ \\
\hline $\mathrm{C} 24 \mathrm{n}$ & 0.983 & 1.363 & 1.360 & & & & $1.554 \pm 0.043$ & & $1.271 \pm 0.094$ \\
\hline
\end{tabular}

ration for $\mathrm{C} 22 \mathrm{r}$, a $335 \mathrm{kyr}$ longer duration for $\mathrm{C} 23 \mathrm{n} .2 \mathrm{n}$, and a $283 \mathrm{kyr}$ shorter duration for C24n compared to previous marine records (Westerhold et al., 2015). The 50 Ma discrepancy in seafloor spreading rates is now eliminated. It was clearly the effect of the difficult and incomplete identification of Chron C23n at Site 1258. Moreover, the durations are consistent within error to the GPTS2012 (Vandenberghe et al., 2012) except for Chron C20r, which is difficult to access due to the relatively large error for the radioisotopic ages of the Mission Valley and the Montanari ash (Fig. 6) (for discussion see Westerhold et al., 2015). At this point more precise estimates of the mean width of magnetic anomalies and their error are required to be able to evaluate and improve the GPTS in the late Eocene. However, comparison to the GPTS models from terrestrial successions corroborates the finding (Westerhold et al., 2015) that the model of Tsukui and Clyde (2012) more closely resembles the marine GPTS than the model of Smith et al. (2010, 2014) (Fig. 6). Issues in the correlation of the Layered tuff, Sixth tuff, and Main tuff to local magnetostratigraphic records in the terrestrial records from the Green River Formation need to be resolved (see Tsukui and Clyde, 2012) to understand the current discrepancies in various terrestrial and marine GPTS models.

\subsection{Defining the age of the top and bottom of the Ypresian stage}

The GSSP of the Ypresian, which also marks the PaleoceneEocene boundary, is defined at the basal inflection of the CIE of the PETM (Aubry et al., 2007), about two-thirds of the way down in magnetochron C24r (Westerhold et al., 2007) at the base of Zone CNE1 where the top of the calcareous nannofossil Fasciculithus richardii group and the base of calcareous nannofossil excursion taxa (CNET) occur (Westerhold et al., 2007, 2015; Agnini et al., 2014). The age and position of the onset of the PETM is confirmed by our study and thus needs no further discussion.

The top of the Ypresian stage (or base of the Lutetian) is defined at the lowest occurrence of the calcareous nannofossil Blackites inflatus (CP12a-CP12b boundary; Okada and Bukry, 1980) in the Gorrondatxe sea cliff section in Basque Country, northern Spain (Molina et al., 2011). The lowest occurrence of $B$. inflatus is reported $\sim 819 \mathrm{kyr}$ (39 precession cycles) after the base of Chron C21r (Bernaola et al., 2006; Payros et al., 2009), or $60 \%$ up in Chron C21r (C21r.6), leading to an age of $\sim 47.8 \mathrm{Ma}$ using GPTS2012 (Vandenberghe et al., 2012). The new YATS absolute ages for the C21n$\mathrm{C} 21 \mathrm{r}(47.834 \mathrm{Ma})$ and $\mathrm{C} 21 \mathrm{r}-\mathrm{C} 22 \mathrm{n}(48.994 \mathrm{Ma})$ boundaries result in a $500 \mathrm{kyr}$ older top of the Ypresian (= base of $B$. inflatus; C21r.6 will be $48.3 \mathrm{Ma}$ ). However, when data from the Gorrondatxe reference section are compared with those from Site 1258 and SE Newfoundland Ridge (Norris et al., 2014), a large discrepancy emerges in the position of the base of $B$. inflatus, which is located near the bottom of Chron C21n outside the GSSP section (Fig. 5) and has a tuned age of $47.686 \pm 0.065 \mathrm{Ma}$. According to Agnini et al. (2014), $B$. inflatus is more abundant in shallow water or hemipelagic settings and is rarely observed in pelagic settings. Furthermore, and importantly, few data exist that provide a precise tie to magnetostratigraphy. Diachronicity for some nannofos- 
Table 3. Overview of naming and age of hyperthermal events.

\begin{tabular}{|c|c|c|c|c|c|}
\hline \multicolumn{4}{|c|}{ Hyperthermal naming scheme } & \multirow{2}{*}{$\begin{array}{c}\text { Tuned age } \\
\text { Ma } \\
\text { La2010b }\end{array}$} & \multirow[t]{2}{*}{ Comment } \\
\hline $\begin{array}{c}\text { Sexton } \\
\text { et al., (2011) }\end{array}$ & $\begin{array}{c}\text { Kirtland-Turner } \\
\text { et al., (2014) }\end{array}$ & $\begin{array}{c}\text { Cramer et al., (2003) } \\
\text { Lauretano et al., (2016) }\end{array}$ & $\begin{array}{r}\text { This } \\
\text { study }\end{array}$ & & \\
\hline $\mathrm{C} 21 \mathrm{rH} 6$ & $\mathrm{C} 21 \mathrm{rH} 5$ & - & $\mathrm{C} 21 \mathrm{rH} 5$ & 48.075 & \\
\hline $\mathrm{C} 21 \mathrm{rH} 5$ & $\mathrm{C} 21 \mathrm{rH} 4$ & - & $\mathrm{C} 21 \mathrm{rH} 4$ & 48.365 & \\
\hline $\mathrm{C} 21 \mathrm{rH} 4$ & $\mathrm{C} 21 \mathrm{rH} 3$ & - & $\mathrm{C} 21 \mathrm{rH} 3$ & 48.450 & \\
\hline $\mathrm{C} 21 \mathrm{rH} 3$ & - & - & - & - & not crossing the $1 \sigma$ level of Kirtland-Turner et al., 2014 \\
\hline $\mathrm{C} 21 \mathrm{rH} 2$ & $\mathrm{C} 21 \mathrm{rH} 2$ & - & $\mathrm{C} 21 \mathrm{rH} 2$ & 48.765 & \\
\hline $\mathrm{C} 21 \mathrm{rH} 1$ & $\mathrm{C} 21 \mathrm{rH} 1$ & - & $\mathrm{C} 21 \mathrm{rH} 1$ & 48.850 & \\
\hline $\mathrm{C} 22 \mathrm{nH} 4$ & $\mathrm{C} 22 \mathrm{nH} 5$ & - & $\mathrm{C} 22 \mathrm{nH} 5$ & 49.140 & \\
\hline $\mathrm{C} 22 \mathrm{nH} 3$ & $\mathrm{C} 22 \mathrm{nH} 4$ & - & $\mathrm{C} 22 \mathrm{nH} 4$ & 49.250 & \\
\hline- & $\mathrm{C} 22 \mathrm{nH} 3$ & - & $\mathrm{C} 22 \mathrm{nH} 3$ & 49.385 & added by Kirtland-Turner et al., 2014 \\
\hline $\mathrm{C} 22 \mathrm{nH} 2$ & $\mathrm{C} 22 \mathrm{nH} 2$ & W & $\mathrm{C} 22 \mathrm{nH} 2$ & 49.585 & \\
\hline $\mathrm{C} 22 \mathrm{nH} 1$ & $\mathrm{C} 22 \mathrm{nH} 1$ & $\mathrm{~V}$ & $\mathrm{C} 22 \mathrm{nH} 1$ & 49.685 & \\
\hline $\mathrm{C} 22 \mathrm{rH} 3$ & $\mathrm{C} 22 \mathrm{rH} 6$ & - & - & - & no clear $\mathrm{d} 13 \mathrm{C}$ and $\mathrm{d} 180$ excursion \\
\hline $\mathrm{C} 22 \mathrm{rH} 2$ & $\mathrm{C} 22 \mathrm{rH} 5$ & $\mathrm{U}$ & $\mathrm{C} 22 \mathrm{rH} 5$ & 49.950 & \\
\hline $\mathrm{C} 22 \mathrm{rH} 1$ & - & - & - & - & not crossing the $1 \sigma$ level of Kirtland-Turner et al., 2014 \\
\hline- & $\mathrm{C} 22 \mathrm{rH} 4$ & $\mathrm{~T}$ & $\mathrm{C} 22 \mathrm{rH} 4$ & 50.370 & \\
\hline- & $\mathrm{C} 22 \mathrm{rH} 3$ & $\mathrm{~S}$ & $\mathrm{C} 22 \mathrm{rH} 3$ & 50.485 & \\
\hline- & $\mathrm{C} 22 \mathrm{rH} 2$ & $\mathrm{R}$ & $\mathrm{C} 22 \mathrm{rH} 2$ & 50.670 & \\
\hline- & $\mathrm{C} 22 \mathrm{rH} 1$ & Q & $\mathrm{C} 22 \mathrm{rH} 1$ & 50.760 & \\
\hline- & $\mathrm{C} 23 \mathrm{n} .1 \mathrm{nH} 1$ & $\mathrm{P}$ & $\mathrm{C} 23 \mathrm{n} .1 \mathrm{nH} 1$ & 50.865 & \\
\hline- & $\mathrm{C} 23 \mathrm{n} .2 \mathrm{nH} 1$ & $\mathrm{O}$ & $\mathrm{C} 23 \mathrm{n} \cdot 2 \mathrm{nH} 2$ & 51.230 & name adjusted to revised magnetostratigraphy \\
\hline- & $\mathrm{C} 23 \mathrm{rH} 3$ & $\mathrm{~N}$ & $\mathrm{C} 23 \mathrm{n} .2 \mathrm{nH} 1$ & 51.550 & name adjusted to revised magnetostratigraphy \\
\hline- & $\mathrm{C} 23 \mathrm{rH} 2$ & M & $\mathrm{C} 23 \mathrm{rH} 2$ & 51.970 & \\
\hline- & $\mathrm{C} 23 \mathrm{rH} 1$ & $\mathrm{~L}$ & $\mathrm{C} 23 \mathrm{rH} 1$ & 52.460 & \\
\hline- & $\mathrm{C} 24 \mathrm{n} .1 \mathrm{nH} 1$ & K/ETM-3 & $\mathrm{C} 24 \mathrm{n} .1 \mathrm{nH} 1$ & 52.845 & \\
\hline- & - & $\mathrm{J}$ & $\mathrm{C} 24 \mathrm{n} .2 \mathrm{rH} 1$ & 53.260 & not crossing the $1 \sigma$ level of Kirtland-Turner et al., 2014 \\
\hline- & $\mathrm{C} 24 \mathrm{n} .3 \mathrm{nH} 2$ & $\mathrm{I} 2$ & $\mathrm{C} 24 \mathrm{n} .3 \mathrm{nH} 2$ & 53.545 & \\
\hline- & $\mathrm{C} 24 n .3 \mathrm{nH} 1$ & I1 & $\mathrm{C} 24 \mathrm{n} .3 \mathrm{nH} 1$ & 53.665 & \\
\hline- & $\mathrm{C} 24 \mathrm{rH} 9$ & $\mathrm{H} 2$ & $\mathrm{C} 24 \mathrm{rH} 9$ & 53.950 & \\
\hline- & $\mathrm{C} 24 \mathrm{rH} 8$ & H1/ETM-2 & $\mathrm{C} 24 \mathrm{rH} 8$ & 54.050 & \\
\hline- & $\mathrm{C} 24 \mathrm{rH} 7$ & $\mathrm{~F}$ & $\mathrm{C} 24 \mathrm{rH} 7$ & 55.165 & \\
\hline- & $\mathrm{C} 24 \mathrm{rH} 6$ & E2 & $\mathrm{C} 24 \mathrm{rH} 6$ & 55.555 & \\
\hline- & $\mathrm{C} 24 \mathrm{rH} 5$ & E1 & $\mathrm{C} 24 \mathrm{rH} 5$ & 55.650 & \\
\hline- & PETM & PETM & PETM & 55.930 & \\
\hline
\end{tabular}

sil events is well documented in the high-resolution astronomically calibrated bio- and magnetostratigraphy for Leg 208 sites and Site 1258 presented here. However, an offset of more than $600 \mathrm{kyr}(48.3-47.686 \mathrm{Ma})$ between the Integrated Ocean Drilling Program (IODP) Atlantic sites and the Gorrondatxe section, resulting from the inconsistent position in $\mathrm{C} 21 \mathrm{n}$ rather than $\mathrm{C} 21 \mathrm{r} .6$, suggests that either the base of $B$. inflatus might not be the perfect global marker for the Ypresian-Lutetian boundary or the quality of magnetostratigraphic data in the Spanish section is not appropriate. Additional work on deep marine and hemipelagic records with good magnetostratigraphy is required to test the consistency of the position of this biohorizon and the relative ranking and spacing with the base of Nannotetrina cristata that is reported to occur very close to the base of B. inflatus and Chron C21n (Agnini et al., 2014; Norris et al., 2014).

\subsection{Hyperthermal events}

The Ypresian stage is of special interest to recent scientific work because it allows the study of climate dynamics and feedbacks in a warm world (Zachos et al., 2008). In particular, the occurrence of multiple transient global warming events (hyperthermals) could help tremendously to understand the response of the climate system to a massive release of carbon to the ocean-atmosphere system (Dickens, 2003; Zachos et al., 2008; Lunt et al., 2011; Kirtland Turner et al., 2014). A paired negative excursion in the carbon and oxygen isotope composition of bulk sediment and benthic foraminifera associated with a more clay-rich layer, indicating dissolution of carbonate, are the characteristics of the deep-marine hyperthermal events (Zachos et al., 2005; Lourens et al., 2005; Leon-Rodriguez and Dickens, 2010). The early Eocene hyperthermals are paced by Earth's orbital eccentricity, except for the PETM (Zachos et al., 2010; Sexton et al., 2011; Littler et al., 2014; Lauretano et al., 2015, 2016; Laurin et al., 2016). After the discovery of a large number of early Eocene hyperthermal events, a magnetochron- 
based naming scheme was introduced (Sexton et al., 2011; Kirtland Turner et al., 2014). Because the scheme used the inaccurate magnetostratigraphy of Site 1258 for Chrons C21 to $\mathrm{C} 24$, we updated the naming scheme of Kirtland Turner et al. (2014). We also maintain the labeling system of Cramer et al. (2003), which was extended by Lauretano et al. (2016) for consistency. In Table 3 we provide an overview of the naming schemes, astronomical age, and position with respect to magnetostratigraphy.

The most important characteristic used to identify hyperthermal events is a paired excursion in $\delta^{13} \mathrm{C}$ and $\delta^{18} \mathrm{O}$ isotope data of preferably benthic foraminifera as in Sexton et al. (2011). However, some of the events defined in Sexton et al. (2011) fail this criterion but have still been considered as hyperthermals if the excursions are more negative than $1 \sigma$ beyond the mean of its $2 \mathrm{Myr}$ running average (Kirtland Turner et al., 2014). This kind of test was applied to both benthic and bulk stable isotope data. It can be questioned if the bulk stable isotope data alone are sufficient to identify a hyperthermal event as several other factors can influence bulk sediment composition (e.g., production and preservation). To definitely identify hyperthermal events in the entire Ypresian, paired high-resolution benthic stable $\delta^{13} \mathrm{C}$ and $\delta^{18} \mathrm{O}$ values are needed. These records are available from PETM to the C24n.2rH1 event (Littler et al., 2014) and from the C22rH5 to C21rH5 events (Sexton et al., 2011). Unfortunately, the published record from Site 1263 (Lauretano et al., 2016), which spans from ETM-2 (H1) to the C22nH2 (W) event, only provides benthic $\delta^{13} \mathrm{C}$ data. To definitely identify hyperthermals in the Ypresian, more stable paired benthic isotope data are needed. Hence, we refrain from changing or even making up a new naming scheme. We synthesized the available schemes and adopted the naming in Table 3 here as well as provided their astronomical ages from the new astrochronology (Fig. 5).

\section{Conclusions}

A new complex cyclostratigraphy and refined bio-, chemo-, and magnetostratigraphy have been developed for key ODP records spanning the entire Ypresian stage from 56 to $47 \mathrm{Ma}$. Detailed correlation of ODP Sites 1258, 1262, 1263, 1265, and 1267 using the new CODD macros software tool revealed a 3-400 kyr condensed interval at the Leg 208 sites during Chron C22n. New characteristic remanent magnetization data from four Leg 208 sites show an overall consistent magnetostratigraphy refining the Ypresian geomagnetic polarity timescale. Multi-site ChRM data correlated on a centimeter to decimeter scale suggest that a magnetostratigraphic record from a single site might contain significant errors due to coring disturbance. Cyclic variations in synthesized XRF core scanning and stable isotope data as well as lithological changes apparent in core images have been successfully used to refine previous astrochronologies and con- struct the first complete Ypresian astronomical timescale. In the absence of independent, high-precision time-control-like radioisotopic dates in Leg 207 and 208 sediments, our study clearly validates that it is crucial to combine multiple records from multiple regions to help safeguard against incompleteness that is otherwise difficult to assess both qualitatively and quantitatively. The YATS not only provides updated absolute ages for bio- and magnetostratigraphy but also a comprehensive list of the early Eocene hyperthermal events. The new astronomically calibrated Ypresian GPTS resolves the $50 \mathrm{Ma}$ discrepancy, which was primarily caused by the imprecise magnetostratigraphy of Site 1258 . Comparing the eccentricity-related cyclic pattern in XRF core scanning and stable carbon isotope data to numerical orbital solutions suggests that the transition from libration to circulation as predicted by the La2010b solution occurred $\sim 52 \mathrm{Ma}$. This adds to the geological evidence for the chaotic nature in the evolution of the solar system.

Data availability. The data reported in this paper are tabulated in the Supplement and archived in the PANGAEA (https://doi. pangaea.de/10.1594/PANGAEA.871246; Westerhold et al., 2017) database.

\section{The Supplement related to this article is available online at https://doi.org/10.5194/cp-13-1129-2017-supplement.}

Competing interests. The authors declare that they have no conflict of interest.

Acknowledgements. We thank Henning Kuhnert and his team for stable isotope analyses at MARUM, Alex Wülbers and Walter Hale at the IODP Bremen Core Repository (BCR) for core handling, and Vera Lukies (MARUM) for assistance with XRF core scanning. We thank Frits Hilgen, Stephen R. Meyers, and the anonymous referee for their constructive critical reviews. This research used samples and data provided by the International Ocean Discovery Program (IODP). IODP is sponsored by the US National Science Foundation (NSF) and participating countries. Financial support for this research was provided by the Deutsche Forschungsgemeinschaft (DFG) and the National Science Foundation (NSF).

The article processing charges for this open-access publication were covered by the University of Bremen.

Edited by: Appy Sluijs

Reviewed by: Frederik Hilgen, Stepen Meyers, and one anonymous referee 


\section{References}

Agnini, C., Fornaciari, E., Raffi, I., Rio, D., Röhl, U., and Westerhold, T.: High-resolution nannofossil biochronology of middle Paleocene to early Eocene at ODP Site 1262: Implications for calcareous nannoplankton evolution, Marine Micropaleontol., 64, 215-248, https://doi.org/10.1016/j.marmicro.2007.05.003, 2007.

Agnini, C., Macri, P., Backman, J., Brinkhuis, H., Fornaciari, E., Giusberti, L., Luciani, V., Rio, D., Sluijs, A., and Speranza, F.: An early Eocene carbon cycle perturbation at $52.5 \mathrm{Ma}$ in the Southern Alps: Chronology and biotic response, Paleoceanography, 24, PA2209, https://doi.org/10.1029/2008pa001649, 2009.

Agnini, C., Fornaciari, E., Raffi, I., Catanzariti, R., Pälike, H., Backman, J., and Rio, D.: Biozonation and biochronology of Paleogene calcareous nannofossils from low and middle latitudes, Newsl. Stratigr., 47, 131-181, https://doi.org/10.1127/00780421/2014/0042, 2014.

Aubry, M. P., Ouda, K., Dupuis, C., Berggren, W. A., Van Couvering, J. A., and the Members of the Working Group on the Paleocene/Eocene Boundary: The Global Standard Stratotypesection and Point (GSSP) for the base of the Eocene Series in the Dababiya section (Egypt), Episodes, 30, 271-286, 2007.

Backman, J. and Shackleton, N. J.: Quantitative biochonology of Pliocene and early Pleistocene calcareous nannofossils from the Atlantic, Indian and Pacific Ocean, Mar. Micropaleontol., 8, 141-170, 1983.

Bernaola, G., Orue-Etxebarria, X., Payros, A., Dinarès-Turell, J., Tosquella, J., Estibaliz, A., and Caballero, F.: Biomagnetostratigraphy analysis of the Gorrondatx section (Basque Country, Western Pyrenees): Its significance for the definition of the Ypresian/Lutetian boundary stratotype, N. Jb. Geol. Paläont. Abh., 241, 67-109, 2006.

Bown, P. R. Young, J. R.: Techniques, in: Calcareous Nannofossil Biostratigraphy, edited by: Bown, P. R., Kluwer Academic, London, 16-28, 1998.

Broecker, W. S. and Peng, T. H.: Tracers in the Sea, University, C., Lamont Doherty Geol. Obs. Publications, New York, 689 pp., 1982.

Cande, S. C. and Kent, D. V.: A New Geomagnetic Polarity Time Scale for the late Cretaceous and Cenozoic, J. Geophys. Res., 97, 13917-13951, 1992.

Cande, S. C. and Kent, D. V.: Revised calibration of the geomagnetic polarity timescale for the Late Cretaceous and Cenozoic, J. Geophys. Res., 100, 6093-6095, 1995.

Clyde, W. C., Hamzi, W., Finarelli, J. A., Wing, S. L., Schankler, D., and Chew, A.: Basin-wide magnetostratigraphic framework for the Bighorn Basin, Wyoming, GSA Bulletin, 119, 848-859, 2007.

Cramer, B. S., Wright, J. D., Kent, D. V., and Aubry, M.-P.: Orbital climate forcing of $\delta^{13} \mathrm{C}$ excursions in the late Paleocene - Eocene (chrons C24n-C25n), Paleoceanography, 18, 1097, https://doi.org/10.1029/2003PA000909, 2003.

Dickens, G. R.: Rethinking the global carbon cycle with a large, dynamic and microbially mediated gas hydrate capacitor, Earth Planet. Sc. Lett., 213, 169-183, https://doi.org/10.1016/S0012821X(03)00325-X, 2003.
Erbacher, J., Mosher, D. C., Malone, M. J., and et al.: Proc. ODP, Init. Repts., 207: College Station, TX, Ocean Drilling Program, 2004.

Fienga, A., Manche, H., Laskar, J., and Gastineau, M.: INPOP06: a new numerical planetary ephemeris, Astron. Astrophys., 477, 315-327, https://doi.org/10.1051/0004-6361:20066607, 2008.

Fienga, A., Laskar, J., Morley, T., Manche, H., Kuchynka, P., Le Poncin-Lafitte, C., Budnik, F., Gastineau, M., and Somenzi, L.: INPOP08, a 4-D planetary ephemeris: from asteroid and time-scale computations to ESA Mars Express and Venus Express contributions, Astron. Astrophys., 507, 1675-1686, https://doi.org/10.1051/0004-6361/200911755, 2009.

Fienga, A., Laskar, J., Kuchynka, P., Manche, H., Desvignes, G., Gastineau, M., Cognard, I., and Theureau, G.: The INPOP10a planetary ephemeris and its applications in fundamental physics, Celestial Mechanics and Dynamical Astronomy, 111, 363-385, https://doi.org/10.1007/s10569-011-9377-8, 2011.

Galeotti, S., Krishnan, S., Pagani, M., Lanci, L., Gaudio, A., Zachos, J. C., Monechi, S., Morelli, G., and Lourens, L.: Orbital chronology of Early Eocene hyperthermals from the Contessa Road section, central Italy, Earth Planet. Sc. Lett., 290, 192-200, https://doi.org/10.1016/j.eps1.2009.12.021, 2010.

Gingerich, P. D.: Mammalian responses to climate change at the Paleocene-Eocene boundary: Polecat Bench record in the northern Bighorn Basin, Wyoming, in: Causes and Consequences of Globally Warm Climates in the Early Paleogene, edited by: Wing, S. L., Gingerich, P. D., Schmitz, B., and Thomas, E., Geological Society of America Special Paper, Geological Society of America, Boulder, Colorado, 463-478, 2003.

Hilgen, F. J., Hinnov, L. A., Abdul Aziz, H., Abels, H. A., Batenburg, S., Bosmans, J. H. C., de Boer, B., Hüsing, S. K., Kuiper, K. F., Lourens, L. J., Rivera, T., Tuenter, E., Van de Wal, R. S. W., Wotzlaw, J.-F., and Zeeden, C.: Stratigraphic continuity and fragmentary sedimentation: the success of cyclostratigraphy as part of integrated stratigraphy, Geological Society, London, Special Publications, 404, 157-197, https://doi.org/10.1144/sp404.12, 2014.

Hinnov, L. A.: New Perspectives on Orbitally Forced Stratigraphy, Annu. Rev. Earth Planet. Sc., 28, 419-475, 2000.

Hinnov, L. A.: Cyclostratigraphy and its revolutionizing applications in the earth and planetary sciences, Geol. Soc. Am. Bull., 125, 1703-1734, 10.1130/b30934.1, 2013.

Ishizuka, O., Tani, K., Reagan, M. K., Kanayama, K., Umino, S., Harigane, Y., Sakamoto, I., Miyajima, Y., Yuasa, M., and Dunkley, D. J.: The timescales of subduction initiation and subsequent evolution of an oceanic island arc, Earth Planet. Sc. Lett., 306, 229-240, https://doi.org/10.1016/j.eps1.2011.04.006, 2011.

Jovane, L., Sprovieri, M., Coccioni, R., Florindo, F., Marsili, A., and Laskar, J.: Astronomical calibration of the middle Eocene Contessa Highway section (Gubbio, Italy), Earth Planet. Sc. Lett., 298, 77-88, https://doi.org/10.1016/j.epsl.2010.07.027, 2010.

Kirschvink, J. L.: The least-squares line and plane and the analysis of paleomagnetic data, Geophys. J. Roy. Astron. Soc., 62, 699718, 1980.

Kirtland Turner, S., Sexton, P. F., Charles, C. D., and Norris, R. D.: Persistence of carbon release events through the peak of early Eocene global warmth, Nat. Geosci., 7, 748-751, https://doi.org/10.1038/ngeo2240, 2014. 
Kuiper, K. F., Deino, A., Hilgen, F. J., Krijgsman, W., Renne, P. R., and Wijbrans, J. R.: Synchronizing Rock Clocks of Earth History, Science, 320, 500-504, https://doi.org/10.1126/science.1154339, 2008.

Laskar, J.: A numerical experiment on the chaotic behaviour of the Solar System, Nature, 338, 237-238, 1989.

Laskar, J.: The limits of Earth orbital calculations for geological time-scale use, Philos. T. R. Soc. Lond., 357, 1735-1759, 1999.

Laskar, J., Joutel, F., and Boudin, F.: Orbital, precessional, and insolation quantities for the earth from $-20 \mathrm{Myr}$ to $+10 \mathrm{Myr}$, Astron. Astrophys., 270, 522-533, 1993.

Laskar, J., Robutel, P., Joutel, F., Gastineau, M., Correia, A., and Levrard, B.: A long-term numerical solution for the insolation quantities of the Earth, Astron. Astrophys., 428, 261-285, https://doi.org/10.1051/0004-6361:20041335, 2004.

Laskar, J., Fienga, A., Gastineau, M., and Manche, H.: La2010: a new orbital solution for the long-term motion of the Earth, Astron. Astrophys., 532, A89, https://doi.org/10.1051/00046361/201116836, 2011a.

Laskar, J., Gastineau, M., Delisle, J. B., Farrés, A., and Fienga, A.: Strong chaos induced by close encounters with Ceres and Vesta, Astron. Astrophys., 532, L4, https://doi.org/10.1051/00046361/201117504, 2011b.

Laurin, J., Meyers, S. R., Galeotti, S., and Lanci, L.: Frequency modulation reveals the phasing of orbital eccentricity during Cretaceous Oceanic Anoxic Event II and the Eocene hyperthermals, Earth Planet. Sc. Lett., 442, 143-156, 2016.

Lauretano, V., Littler, K., Polling, M., Zachos, J. C., and Lourens, L. J.: Frequency, magnitude and character of hyperthermal events at the onset of the Early Eocene Climatic Optimum, Clim. Past, 11, 1313-1324, https://doi.org/10.5194/cp-11-1313-2015, 2015.

Lauretano, V., Hilgen, F. J., Zachos, J. C., and Lourens, L. J.: Astronomically tuned age model for the early Eocene carbon isotope events: A new high-resolution $\delta^{13} \mathrm{C}$ benthic record of ODP Site 1263 between $\sim 49$ and $\sim 54 \mathrm{Ma}$, Newsl. Stratigr., 49, 383-400, https://doi.org/10.1127/nos/2016/0077, 2016.

Leon-Rodriguez, L. and Dickens, G. R.: Constraints on ocean acidification associated with rapid and massive carbon injections: The early Paleogene record at ocean drilling program site 1215 , equatorial Pacific Ocean, Palaeogeogr. Palaeocl., 298, 409-420, https://doi.org/10.1016/j.palaeo.2010.10.029, 2010.

Littler, K., Röhl, U., Westerhold, T., and Zachos, J. C.: A highresolution benthic stable-isotope record for the South Atlantic: Implications for orbital-scale changes in Late Paleocene-Early Eocene climate and carbon cycling, Earth Planet. Sc. Lett., 401, 18-30, https://doi.org/10.1016/j.eps1.2014.05.054, 2014.

Lourens, L. J., Sluijs, A., Kroon, D., Zachos, J. C., Thomas, E., Röhl, U., Bowles, J., and Raffi, I.: Astronomical pacing of late Palaeocene to early Eocene global warming events, Nature, 435, 1083-1087, https://doi.org/10.1038/nature03814, 2005.

Lunt, D. J., Ridgwell, A., Sluijs, A., Zachos, J., Hunter, S., and Haywood, A.: A model for orbital pacing of methane hydrate destabilization during the Palaeogene, Nat. Geosci., 4, 775-778, https://doi.org/10.1038/ngeo1266, 2011.

Ma, C., Meyers, S. R., and Sageman, B. B.: Theory of chaotic orbital variations confirmed by Cretaceous geological evidence, Nature, 542, 468-470, https://doi.org/10.1038/nature21402, 2017.
Machlus, M. L., Ramezani, J., Bowring, S. A., Hemming, S. R., Tsukui, K., and Clyde, W. C.: A strategy for crosscalibrating $\mathrm{U}-\mathrm{Pb}$ chronology and astrochronology of sedimentary sequences: An example from the Green River Formation, Wyoming, USA, Earth Planet. Sc. Lett., 413, 70-78, https://doi.org/10.1016/j.epsl.2014.12.009, 2015.

Martini, E.: Standard Tertiary and Quaternary calcareous nannoplankton zonation, in: Proceedings of the Second Planktonic Conference, edited by: Farinacci, A., Roma 1970, 2. Edizioni Tecnoscienza, Rome, 739-785, 1971.

McCarren, H., Thomas, E., Hasegawa, T., Röhl, U., and Zachos, J. C.: Depth dependency of the Paleocene-Eocene carbon isotope excursion: Paired benthic and terrestrial biomarker records (Ocean Drilling Program Leg 208, Walvis Ridge), Geochem. Geophy. Geosy., 9, Q10008, https://doi.org/10.1029/2008GC002116, 2008.

Meinshausen, M., Smith, S. J., Calvin, K., Daniel, J. S., Kainuma, M. L. T., Lamarque, J. F., Matsumoto, K., Montzka, S. A., Raper, S. C. B., Riahi, K., Thomson, A., Velders, G. J. M., and Vuuren, D. P. P.: The RCP greenhouse gas concentrations and their extensions from 1765 to 2300, Climatic Change, 109, 213-241, https://doi.org/10.1007/s10584-011-0156-z, 2011.

Meyers, S. R.: Astrochron: An R Package for Astrochronology, available at: https://CRAN.R-project.org/package=astrochron (last access: 5 September 2017), 2014.

Meyers, S. R.: The evaluation of eccentricity-related amplitude modulation and bundling in paleoclimate data: An inverse approach for astrochronologic testing and time scale optimization, Paleoceanography, 30, 1625-1640, https://doi.org/10.1002/2015PA002850, 2015.

Molina, E., Alegret, L., Apellaniz, E., Bernaola, G., Caballero, F., Dinarès-Turell, J., Hardenbol, J., Heilmann-Clausen, C., Larrasoana, J. C., Luterbacher, H., Monechi, S., Ortiz, S., OrueEtxebarria, X., Payros, A., Pujalte, V., Rodriguez-Tovar, F. J., Tori, F., Tosquella, J., and Uchman, A.: The Global Stratotype Section and Point (GSSP) for the base of the Lutetian Stage at the Gorrondatxe section, Spain, Episodes, 34, 86-108, 2011.

Norris, R. D., Wilson, P. A., Blum, P., Fehr, A., Agnini, C., Bornemann, A., Boulila, S., Bown, P. R., Cournede, C., Friedrich, O., Ghosh, A. K., Hollis, C. J., Hull, P. M., Jo, K., Junium, C. K., Kaneko, M., Liebrand, D., Lippert, P. C., Liu, Z., Matsui, H., Moriya, K., Nishi, H., Opdyke, B. N., Penman, D., Romans, B., Scher, H. D., Sexton, P., Takagi, H., Turner, S. K., Whiteside, J. H., Yamaguchi, T., and Yamamoto, Y.: Site U1410, Proceedings IODP, 342, 1-87, https://doi.org/10.2204/iodp.proc.342.101.2014, 2014.

O'Connor, J. M., Steinberger, B., Regelous, M., Koppers, A. A. P., Wijbrans, J. R., Haase, K. M., Stoffers, P., Jokat, W., and Garbe-Schönberg, D.: Constraints on past plate and mantle motion from new ages for the Hawaiian-Emperor Seamount Chain, Geochem. Geophy. Geosy., 14, 4564-4584, https://doi.org/10.1002/ggge.20267, 2013.

Ogg, J. G.: Chapter 5 - Geomagnetic Polarity Time Scale, in: The Geologic Time Scale, edited by: Gradstein, F. M., Ogg, J. G., Schmitz, M. D., and Ogg, G. M., Elsevier, Boston, 85-113, https://doi.org/10.1016/B978-0-444-59425-9.00005-6, 2012.

Ogg, J. G. and Smith, A. G.: The geomagnetic polarity time scale, in: A Geological Timescale 2004, edited by: Gradstein, F., Ogg, J., and Smith, A., Cambridge University Press, 63-86, 2004. 
Okada, H. and Bukry, D.: Supplementary modification and introduction of code numbers to the low-latitude coccolith biostratigraphic zonation (Bukry 1973, 1975), Marine Micropaleontol., 5, 321-325, 1980.

Pagani, M., Caldeira, K., Archer, D., and Zachos, J. C.: An Ancient Carbon Mystery, Science, 314, 1556-1557, https://doi.org/10.1126/science.1136110, 2006.

Pälike, H., Laskar, J., and Shackleton, N. J.: Geologic constraints on the chaotic diffusion of the solar system, Geology, 32, 929-932, https://doi.org/10.1130/G20750.1, 2004.

Payros, A., Orue-Etxebarria, X., Bernaola, G., Apellaniz, E., Dinarès-Turell, J., Tosquella, J., and Caballero, F.: Characterization and astronomically calibrated age of the first occurrence of Turborotalia frontosa in the Gorrondatxe section, a prospective Lutetian GSSP: implications for the Eocene time scale, Lethaia, 42, 255-264, https://doi.org/10.1111/j.1502-3931.2008.00142.x, 2009.

Perch-Nielsen, K.: Cenozoic calcareous nannofossils, in: Plankton Stratigraphy, edited by: Bolli, H. M., Saunders, J. B., and PerchNielsen, K., Cambridge University Press, Cambridge, 427-554, 1985.

Röhl, U., Westerhold, T., Bralower, T. J., and Zachos, J. C.: On the duration of the Paleocene-Eocene thermal maximum (PETM), Geochem. Geophy. Geosy., 8, Q12002, https://doi.org/10.1029/2007GC001784, 2007.

Schulz, M., Berger, W. H., Sarnthein, M., and Grootes, P. M.: Amplitude variations of 1470 -year climate oscillations during the last 100,000 years linked to fluctuations of continental ice mass, Geophys. Res. Lett., 26, 3385-3388, 1999.

Sexton, P. F., Norris, R. D., Wilson, P. A., Pälike, H., Westerhold, T., Röhl, U., Bolton, C. T., and Gibbs, S.: Eocene global warming events driven by ventilation of oceanic dissolved organic carbon, Nature, 471, 349-352, https://doi.org/10.1038/nature09826, 2011.

Shackleton, N. J. and Crowhurst, S.: Sediment Fluxes based on an Orbitally Tuned Time Scale 5 to $14 \mathrm{Ma}$, Site 926, in: Proc. ODP, Sci. Results, 154, College Station, TX (Ocean Drilling Program), edited by: Shackleton, N. J., Curry, W. B., Richter, C., and Bralower, T. J., 69-82, https://doi.org/10.2973/odp.proc.sr.154.102.1997, 1997.

Slotnick, B. S., Dickens, G. R., Nicolo, M. J., Hollis, C. J., Crampton, J. S., Zachos, J. C., and Sluijs, A.: Large-Amplitude Variations in Carbon Cycling and Terrestrial Weathering during the Latest Paleocene and Earliest Eocene: The Record at Mead Stream, New Zealand, J. Geol., 120, 487-505, 2012.

Smith, M. E., Chamberlain, K. R., Singer, B. S., and Carroll, A. R.: Eocene clocks agree: Coeval 40Ar/39Ar, U-Pb, and astronomical ages from the Green River Formation, Geology, 38, 527-530, https://doi.org/10.1130/g30630.1, 2010.

Smith, M. E., Carroll, A. R., Scott, J. J., and Singer, B. S.: Early Eocene carbon isotope excursions and landscape destabilization at eccentricity minima: Green River Formation of Wyoming, Earth Planet. Sc. Lett., 403, 393-406, https://doi.org/10.1016/j.epsl.2014.06.024, 2014.

Stap, L., Sluijs, A., Thomas, E., and Lourens, L.: Patterns and magnitude of deep sea carbonate dissolution during Eocene Thermal Maximum 2 and H2, Walvis Ridge, southeastern Atlantic Ocean, Paleoceanography, 24, PA1211, https://doi.org/10.1029/2008PA001655, 2009.
Stap, L., Lourens, L. J., Thomas, E., Sluijs, A., Bohaty, S., and Zachos, J. C.: High-resolution deep-sea carbon and oxygen isotope records of Eocene Thermal Maximum 2 and H2, Geology, 38, 607-610, https://doi.org/10.1130/g30777.1, 2010.

Suganuma, Y. and Ogg, J. G.: Campanian through Eocene magnetostratigraphy of Sites 1257-1261, ODP Leg 207, Demerara Rise (western equatorial Atlantic), in: Proc. ODP, Sci. Results, 207, College Station, TX (Ocean Drilling Program), edited by: Mosher, D. C., Erbacher, J., and Malone, M. J., 1-48, https://doi.org/10.2973/odp.proc.sr.207.102.2006, 2006.

Thomas, E. and Shackelton, N. J.: The Paleocene-Eocene benthic foraminiferal extinctio and stable isotope anomalies, in: Correlation of the Early Paleogene in Northwest Europe, edited by: Knox, R. W. O. B., Corfield, R. M., and Dunay, R. E., Geological Society Special Publication, 401-441, 1996.

Tsukui, K. and Clyde, W. C.: Fine-tuning the calibration of the early to middle Eocene geomagnetic polarity time scale: Paleomagnetism of radioisotopically dated tuffs from Laramide foreland basins, Geol. Soc. Am. Bull., 124, 870-885, https://doi.org/10.1130/b30545.1, 2012.

Vandenberghe, N., Hilgen, F. J., Speijer, R. P., Ogg, J. G., Gradstein, F. M., Hammer, O., Hollis, C. J., and Hooker, J. J.: Chapter 28 The Paleogene Period, in: The Geologic Time Scale, edited by: Gradstein, F. M., Ogg, J. G., Schmitz, M. D., and Ogg, G. M., Elsevier, Boston, 855-921, https://doi.org/10.1016/B978-0-44459425-9.00028-7, 2012.

Wade, B. S. and Pälike, H.: Oligocene climate dynamics, Paleoceanography, 19, PA4019, https://doi.org/10.1029/2004PA001042, 2004.

Westerhold, T. and Röhl, U.: High resolution cyclostratigraphy of the early Eocene - new insights into the origin of the Cenozoic cooling trend, Clim. Past, 5, 309-327, https://doi.org/10.5194/cp-5-309-2009, 2009.

Westerhold, T. and Röhl, U.: Orbital pacing of Eocene climate during the Middle Eocene Climate Optimum and the Chron C19r event: Missing link found in the tropical western Atlantic, Geochem. Geophy. Geosy., 14, 4811-4825, 10.1002/ggge.20293, 2013.

Westerhold, T., Röhl, U., Laskar, J., Bowles, J., Raffi, I., Lourens, L. J., and Zachos, J. C.: On the duration of magnetochrons $\mathrm{C} 24 \mathrm{r}$ and $\mathrm{C} 25 \mathrm{n}$ and the timing of early Eocene global warming events: Implications from the Ocean Drilling Program Leg 208 Walvis Ridge depth transect, Paleoceanography, 22, PA2201, https://doi.org/10.1029/2006PA001322, 2007.

Westerhold, T., Röhl, U., and Laskar, J.: Time scale controversy: Accurate orbital calibration of the early Paleogene, Geochem. Geophy. Geosy., 13, Q06015, https://doi.org/10.1029/2012gc004096, 2012.

Westerhold, T., Röhl, U., Pälike, H., Wilkens, R., Wilson, P. A., and Acton, G.: Orbitally tuned timescale and astronomical forcing in the middle Eocene to early Oligocene, Clim. Past, 10, 955-973, https://doi.org/10.5194/cp-10-955-2014, 2014.

Westerhold, T., Röhl, U., Frederichs, T., Bohaty, S. M., and Zachos, J. C.: Astronomical calibration of the geological timescale: closing the middle Eocene gap, Clim. Past, 11, 1181-1195, https://doi.org/10.5194/cp-11-1181-2015, 2015. 
Westerhold, T., Röhl, U., Frederichs, T., Agnini, C., Raffi, I., Zachos, J. C., and Wilkens, R. H.: Astronomical Calibration of the Ypresian Time Scale, PANGAEA, https://doi.org/10.1594/PANGAEA.871246, 2017.

Whittaker, J. M., Müller, R. D., Leitchenkov, G., Stagg, H., Sdrolias, M., Gaina, C., and Goncharov, A.: Major Australian-Antarctic Plate Reorganization at Hawaiian-Emperor Bend Time, Science, 318, 83-86, https://doi.org/10.1126/science.1143769, 2007.

Wilkens, R. H., Westerhold, T., Drury, A. J., Lyle, M., Gorgas, T., and Tian, J.: Revisiting the Ceara Rise, equatorial Atlantic Ocean: isotope stratigraphy of ODP Leg 154 from 0 to 5 Ma, Clim. Past, 13, 779-793, https://doi.org/10.5194/cp-13779-2017, 2017.

Zachos, J. C., Kroon, D., Blum, P., and et al.: Proc. ODP, Init. Repts., 208, College Station, TX, Ocean Drilling Program, 2004.

Zachos, J. C., Röhl, U., Schellenberg, S. A., Sluijs, A., Hodell, D. A., Kelly, D. C., Thomas, E., Nicolo, M., Raffi, I., Lourens, L. J., McCarren, H., and Kroon, D.: Rapid Acidification of the Ocean During the Paleocene-Eocene Thermal Maximum, Science, 308, 1611-1615, https://doi.org/10.1126/science.1109004, 2005.

Zachos, J. C., Dickens, G. R., and Zeebe, R. E.: An early Cenozoic perspective on greenhouse warming and carbon-cycle dynamics, Nature, 451, 279-283, https://doi.org/10.1038/nature06588, 2008 .
Zachos, J. C., McCarren, H., Murphy, B., Röhl, U., and Westerhold, T.: Tempo and scale of late Paleocene and early Eocene carbon isotope cycles: Implications for the origin of hyperthermals, Earth Planet. Sc. Lett., 299, 242-249, https://doi.org/10.1016/j.epsl.2010.09.004, 2010.

Zeebe, R. E., Westerhold, T., Littler, K., and Zachos, J. C.: Orbital forcing of the Paleocene and Eocene carbon cycle, Paleoceanography, 32, 440-465, https://doi.org/10.1002/2016PA003054, 2017.

Zeeden, C., Hilgen, F., Westerhold, T., Lourens, L., Röhl, U., and Bickert, T.: Revised Miocene splice, astronomical tuning and calcareous plankton biochronology of ODP Site 926 between 5 and 14.4 Ma, Palaeogeogr. Palaeocl., 369, 430-451, https://doi.org/10.1016/j.palaeo.2012.11.009, 2013.

Zeeden, C., Hilgen, F. J., Hüsing, S. K., and Lourens, L. L.: The Miocene astronomical time scale 9-12 Ma: New constraints on tidal dissipation and their implications for paleoclimatic investigations, Paleoceanography, 29, 296-307, https://doi.org/10.1002/2014PA002615, 2014.

Zeeden, C., Meyers, S. R., Lourens, L. J., and Hilgen, F. J.: Testing astronomically tuned age models, Paleoceanography, 30, 369383, https://doi.org/10.1002/2014PA002762, 2015. 